\title{
THE OFFICLAL DEVELOPMENT ASSISTANCE ACCOUNTABILITY ACT: GLOBAL JUSTICE AND MANAGERIALISM IN CANADIAN LAW
}

\author{
DEREK McKEE
}

\section{INTRODUCTION}

Globalization presents certain dilemmas for domestic law. Global movements of people, things, and symbols have created a dense web of transnational connections and have made people increasingly aware of these relationships. Such changes problematize the Westphalian assumption that the territorial state should provide the frame for debates about justice. ${ }^{1}$ Nevertheless, state laws and institutions are typically founded on a territorially-bounded notion of democracy. Although these laws and institutions may be mobilized to remedy injustices beyond the state, the intended beneficiaries of such initiatives have little if any say in the process. State lawmakers who want to respond to global injustices thus need some way of overcoming this apparent democratic deficit.

Assistant Professor, Faculty of Law, Université de Sherbrooke. This article is based on a case study undertaken as part of my doctoral dissertation at the Faculty of Law, University of Toronto, defended in 2013. I would like to thank my supervisor, Kerry Rittich, for her support and guidance. I would also like to thank the members of my dissertation committee, David Schneiderman and Lorne Sossin. Others who have provided helpful comments on previous drafts include Amaya Álvez Marín, Amar Bhatia, Matthew Craven, Patrícia Galvão Ferreira, Frances Foster-Thorpe, Angela Keller-Herzog, Karen Knop, Audrey Macklin, Umut Özsu, Nicolas Rouleau, Sara Seck, Rayner Thwaites, and participants in the Some Institutes for Advanced Study "Regulating the World Society" Summer Institute, held in Bloomington, Indiana, in July 2012. Finally, I would like to thank the numerous government officials, NGO staff members, and others who allowed me to interview them, generally on condition of anonymity. Mistakes are mine.

1 See Nancy Fraser, Scales of Justice: Reimagining Political Space in a Globalizing World (New York: Columbia University Press, 2009) at 12-21. 
This article illustrates this dilemma and explores their implications through an analysis of a recent Canadian statute, the Official Development Assistance Accountability Act. ${ }^{2}$ Enacted in 2008, this law requires cabinet ministers responsible for the provision of Canadian aid to be of the opinion that this aid contributes to poverty reduction, takes into account the perspectives of the poor, and conforms to international human rights standards. ${ }^{3}$ It also mandates a series of reports in which the government is meant to document its compliance with these requirements. ${ }^{4}$

As this article explains, the creation of the ODA Accountability Act was championed by a small group of activists who wanted Canadian aid to respond to global injustices, understood in terms of poverty, inequality, and human rights violations. This article describes how these activists faced resistance from various actors, mainly representing the government, who thought that aid should promote Canadian economic and security interests. The debates surrounding the Act thus reflected basic disagreements about the appropriate frame for questions of justice. Nevertheless, the political debate surrounding the ODA Accountability Act was largely a domestic affair, in which almost all of the participants were Canadian. The proponents of the Act employed a number of strategies to overcome this democratic deficit. Foremost among these strategies was an appeal to a managerial conception of development assistance. Another important strategy was the incorporation of norms and standards borrowed from international organizations.

This article argues that neither of these approaches provides a satisfactory response to democratic concerns. Managerialism purportedly transforms political conflicts into technical problems to be resolved through the application of expert knowledge. But the ways these problems are defined, and the ways this knowledge is generated and applied, are themselves highly political. And the

\footnotetext{
2 SC 2008, c 17 [ODA Accountability Act].

3 Ibid, $\mathrm{s} 4(1)$.

$4 \quad I b i d, \mathrm{~s} 5$.
} 
international organizations that generate norms and standards related to development assistance can be said to suffer from democratic deficits of their own. Moreover, the norms and standards produced by these organizations tend to be compatible with an expert-led, managerial form of governance.

The theoretical building blocks of this argument appear in Part 2 of this article. I begin with a brief discussion of globalization and its implications for debates about justice. Different accounts of global justice are expressed in different approaches to development assistance policy. However, the governance of development assistance tends to be infused with a managerial ethos that allows development agencies to sidestep these questions. I also examine the role of donor country legislation in development assistance. The example of the United Kingdom's International Development Act $2002^{5}$ shows that the existence of a statutory framework for aid does not preclude a managerial approach.

In Part 3 of this article, I describe the ODA Accountability Act and tell the story of its creation. Participants in the debates surrounding the Act expressed different visions of global justice. Nevertheless, the legislative process was essentially a domestic matter and therefore appears to have involved a democratic deficit. However, the proponents of the $O D A$ Accountability Act appealed to a managerial conception of development assistance in order to bypass such questions of democracy. Although the proponents at times acknowledged shortcomings in the way development assistance is governed, their preferred solution was to confer more discretionary authority on those perceived as having the expertise to manage aid properly.

In Part 4, I examine the role of globalized norms and standards. The ODA Accountability Act incorporates a number of norms and standards borrowed from international development assistance organizations. In principle, recourse to such instruments might be imagined as a way of overcoming any democratic deficit in the Canadian forum. However,

5 (UK), c 1. 
these norms and standards raise a new set of problems. First, the institutions that generate them are themselves unrepresentative. Second, these institutions, too, tend to promote a managerial response to global poverty that excludes alternative kinds of political claims. Such managerial tendencies can even be observed in the way aid organizations have dealt with human rights. While the proponents of the Act were critical of the democratic deficit in international development institutions, and tried (unsuccessfully) to incorporate such a critique into the Act, they did not call managerialism into question.

In conclusion, I suggest that the case of the ODA Accountability Act has broader implications for the way Canadians (and perhaps citizens of other countries) think about law and globalization. For those with cosmopolitan or internationalist moral commitments, the mobilization of domestic law to combat global injustices holds a strong appeal. However, it is important to consider how such responses may themselves give rise to new kinds of injustice. If one wants to imagine how to respond to global injustice, institutional structures, globalized norms and standards, as well as expert knowledge practices must all be subjected to critical scrutiny.

\section{GLOBALIZATION, JUSTICE, LAW, AND MANAGERIALISM}

In the last few decades, human beings have become increasingly aware of the global interconnectedness of economic, social, and cultural life. Such interconnectedness, often referred to as "globalization", implies that the state might no longer provide an adequate frame for debates about justice. Some domestic lawmakers might even be inclined to modify their own legal systems to reflect transnational moral claims. However, state laws and institutions are not ideal vehicles for global justice. Most importantly, they are typically based on a bounded concept of democracy, and they therefore have a democratic deficit in relation to people beyond their borders. In order to respond to global injustices, state lawmakers must address this democratic deficit.

In this regard, it is worth noting that both state institutions and international organizations have increasingly employed a "managerial" approach to transnational governance. In a managerial approach, 
questions of legal rights and obligations are set aside and replaced by questions of "interests" and "objectives". Managerialism can thus provide an appearance of consensus and a way of avoiding issues that appear overly political. However, as I shall argue, managerialism serves more to conceal the operation of power than to democratize it.

All of these tendencies can be observed in the governance of development assistance. As I shall explain, in the name of "development", donor countries and international organizations distribute material resources to poorer countries in the form of grants, loans, equipment, and commodities. Donors also provide services, or human resources, in the form of education, training, and technical advice. I argue that these transfers have important political implications. Some citizens of donor countries imagine these transfers as responses to global injustices. But development assistance is generally portrayed by its practitioners as a technical rather than a political matter.

\subsection{Globalization, Justice, AND THE Democratic Deficit IN STATE INSTITUTIONS}

The best succinct definition of globalization comes from the philosopher Jürgen Habermas:

By "globalization" is meant the cumulative processes of a worldwide expansion of trade and production, commodity and financial markets, fashions, the media and computer programs, news and communications networks, transportation systems and flows of migration, the risks generated by large-scale technology, environmental damage and epidemics, as well as organized crime and terrorism. ${ }^{6}$

Historians have described globalization as a geographically uneven phenomenon that has ebbed and flowed over the centuries.? Nevertheless, certain aspects of globalization have intensified in recent decades. Between 1990 and 2005, world merchandise trade increased at

6 Jürgen Habermas, The Divided West (Cambridge, UK: Polity Press, 2006) at 175.

7 See Jürgen Osterhammel \& Niels P Petersson, Globalization: A Short History (Princeton, NJ: Princeton University Press, 2005). 
an average rate of almost $6 \%$ per year-more than double the average annual percentage increase in world production during that period. ${ }^{8}$ The anthropologist Arjun Appadurai argues that increases in migration and electronic media since the 1970s have produced a globalization of cultural consciousness that is so novel as to constitute a historical rupture. ${ }^{9}$

Globalization has changed the way many scholars, citizens, and lawmakers think about justice. As the political theorist Nancy Fraser has noted, debates about justice during the immediate postwar era-the heyday of the welfare state in Western Europe and North America-largely focused on the issue of redistribution. Moreover, participants in these debates tended to assume that the state provided the frame in which justice claims could be articulated and in which redistribution, if any, could occur. One's primary obligations of justice were owed to one's fellow citizens. Outside events were conceptualized as security issues or as "humanitarian" concerns rather than questions of justice. ${ }^{10}$

As Fraser notes, the events of recent decades have called into question this "Keynesian-Westphalian" paradigm. First, the growth of feminism and other forms of identity politics have problematized the focus on redistribution, giving equal prominence to questions of recognition. Debates about justice must now address the question of "what?": the relative priority to be accorded to different kinds of justice claims. Second, globalization has made the state seem less appropriate as the site for the institutionalization of justice. ${ }^{11}$ People all over the world experience injustices that appear to be more attributable to outside actors (other states, international organizations, transnational corporations) than to any domestic source. Moreover, since the 1970s, the international human rights movement has provided a popular

8 See WTO, International Trade Statistics 2006 (Geneva: WTO, 2006) at 25.

9 Arjun Appadurai, Modernity at Large: Cultural Dimensions of Globalization (Minneapolis: University of Minnesota Press, 1996) at 2-11,28-31.

10 Fraser, supra note 1 at $12-13$.

11 Ibid at 13-21. 
vocabulary that makes it easier for people to articulate political claims in universal terms. ${ }^{12}$ Finally, since the late 1970 s, philosophers and political theorists have articulated global theories of justice, inspired by Kantian ${ }^{13}$ as well as utilitarian ${ }^{14}$ moral theory. Debates about justice must therefore address the question of "who?": the appropriate political community within which questions of justice should be addressed.

As Fraser explains, responses to this "who" question fall into three different camps. At one end, there are liberal-nationalists, who argue that questions of justice should be settled within each national community. At the other extreme, there are cosmopolitans, who argue that national borders are morally irrelevant, and that obligations of recognition or redistribution are independent of geography. In between are internationalists, who acknowledge transnational moral obligations, but argue that these are somewhat weaker than the moral obligations among citizens of the same country. ${ }^{15}$

These debates about the appropriate frame for justice are relevant in the realm of development assistance. Since the $1940 \mathrm{~s}$, development assistance has been officially described as a response to poverty. ${ }^{16}$ The governments of Western countries (and the international organizations

12 See Samuel Moyn, The Last Utopia: Human Rights in History (Cambridge, Mass: Harvard University Press, 2010).

13 See e.g. Charles R Beitz, Political Theory and International Relations (Princeton, NJ: Princeton University Press, 1979); John Rawls, The Law of Peoples with "The Idea of Public Reason Revisited" (Cambridge, Mass: Harvard University Press, 1999); Thomas Pogge, World Poverty and Human Rights: Cosmopolitan Responsibilities and Reforms (Cambridge, UK: Polity Press, 2002) [Pogge, World Poverty].

14 See e.g. Peter Singer, One World: The Ethics of Globalization (New Haven, Conn: Yale University Press, 2002).

15 Fraser, supra note 1 at 32-33.

16 See Arturo Escobar, Encountering Development: The Making and Unmaking of the Third World (Princeton, NJ: Princeton University Press, 1995) at 22. For example, in the late 1940s the World Bank identified "underdeveloped" countries as those with an annual per capita income of less than US\$100. See Majid Rahnema, "Poverty" in Wolfgang Sachs, ed, The Development Dictionary: A Guide to Knowledge as Power (London, UK: Zed Books, 1992) 158 at 161. 
they established) began to provide development assistance in the $1940 \mathrm{~s}$ and 1950 s at roughly the same time they were constructing their domestic welfare states. Many citizens of donor countries understood development assistance as a projection of social-democratic values onto a global scale. Public support for aid in donor countries has closely tracked public support for domestic welfare policies; aid is more popular on the centre-left than on the centre-right. ${ }^{17}$ Development assistance can therefore be understood as a modest form of redistribution, a response to global inequality as well as poverty.

However, donor countries have also provided development assistance for reasons that have had little to do with poverty or inequality. It was recognized from the outset, in the 1940s, that development assistance was part of a Cold War strategy. For the US government, development assistance was meant to induce other countries to adopt a capitalist economic model and to align themselves with the US against the Soviet Union. Moreover, by "tying" aid to the procurement of their own goods and services, donor countries could use aid as a domestic subsidy. Donors also devised mixed credit schemes, in which aid was used as an incentive to secure commercial deals; aid could also be used to help finance overseas investments by donor country firms, or to build up bilateral trading relationships with particular countries. ${ }^{18}$ Citizens of donor countries who rejected the notion of global redistribution, but merely sought to promote their own countries' national interests, thus found reasons to endorse development assistance programs.

Contemporary debates about aid policy, from the perspective of donor countries, still largely turn on whether and to what extent participants recognize collective moral obligations toward people in other countries. Positions in these policy debates have generally

17 See David Halloran Lumsdaine, Moral Vision in International Politics: The Foreign Aid Regime, 1949-1989 (Princeton, NJ: Princeton University Press, 1993) at 182-90; Alain Noël \& Jean-Philippe Thérien, "From Domestic to International Justice: The Welfare State and Foreign Aid" (1995) 49:3 International Organization 523.

18 See Carol Lancaster, Foreign Aid: Diplomacy, Development, Domestic Politics (Chicago: University of Chicago Press, 2007) at 12-15. 
corresponded to different points on the political spectrum. ${ }^{19}$ Those on the right have generally adopted an "international realist" approach to foreign policy. International realists support aid if and only if it serves the interests of the donor country. International realists have therefore favoured the use of aid for propping up friendly regimes, securing commercial advantages, or providing symbolic expressions of wealth, power, and benevolence. They have seen economic development as incidental to these goals. They have regarded poverty reduction as a humanitarian concern-something better left to private initiative. ${ }^{20}$ The international realist approach to aid policy affirms a strongly nationalist version of justice: obligations of justice are only relevant within the national community. Beyond the border or the water's edge, foreign aid is seen as a matter of charity or prudence, but not a matter of justice.

Closer to the political centre, liberal internationalists have generally seen aid as a way of promoting economic growth. Liberal internationalists therefore endorse expanded trade, which they imagine will benefit both rich and poor countries. ${ }^{21}$ However, in principle, liberal internationalists oppose the use of aid as a subsidy to particular firms or

19 The following analysis is loosely inspired by that found in Cranford Pratt, "Humane Internationalism: Its Significance and Its Variants" in Cranford Pratt, ed, Internationalism under Strain: The North-South Policies of Canada, the Netherlands, Norway, and Sweden (Toronto: University of Toronto Press, 1989) 3 at 13-20 [Pratt, "Humane Internationalism"].

20 See e.g. Keith Spicer, A Samaritan State?: External Aid in Canada's Foreign Policy (Toronto: University of Toronto Press, 1966). For an analogous US perspective, see Samuel P Huntington, "Foreign Aid for What and for Whom" (1970-71) 1 Foreign Policy 161; Samuel P Huntington, "Foreign Aid for What and for Whom (II)" (1971) 2 Foreign Policy 114.

21 See e.g. Paul Collier, The Bottom Billion: Why the Poorest Countries Are Failing and What Can Be Done about It (Oxford: Oxford University Press, 2007). Such ideas can be traced to the work of classical liberal theorists. See e.g. David Ricardo, "On the Principles of Political Economy and Taxation" in Piero Sraffa, ed, The Works and Correspondence of David Ricardo (Cambridge: Cambridge University Press, 1951) vol 1 at 128-49; John Stuart Mill, The Principles of Political Economy: With Some of Their Applications to Social Philosophy, revised ed (London, UK: Colonial Press, $1900)$ vol 2 at $92-124$. 
industries, seeing these as market distortions. ${ }^{22}$ Moreover, applying a Keynesian logic, liberal internationalists have generally concluded that prosperity depends on widespread economic participation, and that the poor require aid during the initial stages of economic growth. They have therefore supported a modestly redistributive approach to aid. ${ }^{23}$ However, liberal internationalists do not necessarily recognize global obligations of distributive justice. The belief that a rising tide will lift all boats allows them to sidestep, to some extent, the question of global inequality and any moral implications it might have.

To the left of centre, social-democratic internationalists have championed the idea that aid should be allocated according to need. ${ }^{24}$ Unlike liberal internationalists, they have explicitly associated aid with the reduction of international economic inequalities, and have drawn an analogy between aid and the redistributive institutions of the welfare state. ${ }^{25}$ Projecting the domestic politics of social democracy onto the international scale, social-democratic internationalists endorse redistribution because it is the right thing to do and because it might help to stave off depression, war, and revolution. ${ }^{26}$ They have therefore promoted "social" forms of aid and argued that these should target the

22 See e.g. Catrinus J Jepma, The Tying of Aid (Paris, France: OECD, 1991).

23 See e.g. Jeffrey D Sachs, The End of Poverty: Economic Possibilities for Our Time (New York: Penguin Press, 2005).

24 See e.g. Brian Tomlinson, "Approaches to Strengthening CIDA: Creating an Effective Government Department for International Cooperation" (2009), online: Canadian Council for International Co-operation (CCIC) <www.ccic.ca>. This normative concern is often expressed in the form of a criticism of aid allocations based on other criteria. See e.g. Thomas Pogge, "Priorities of Global Justice" (2001) 32:1-2 Metaphilosophy 6 at 10 .

25 See e.g. Independent Commission on International Development Issues, North-South: A Program for Survival (Cambridge, Mass: MIT Press, 1980) at $20-21,77$.

26 Ibid. On the politics of social democracy at the domestic level, see generally Tony Judt, Ill Fares the Land (New York: Penguin Press, 2010). 
poorest people in the poorest countries. ${ }^{27}$ They have also argued that donors should behave altruistically. They are critical of the pursuit of commercial and security interests through aid, because they see these as likely to involve departures from a needs-based allocation. ${ }^{28}$ Nevertheless, social-democratic internationalists stop short of full-fledged cosmopolitanism: they do not go so far as to endorse global equalization of income and wealth across countries; they thus affirm that obligations of justice within the national community are somewhat stronger than those beyond it.

These different political orientations-international realism, liberal internationalism, and social-democratic internationalism-are meant as ideal types; they are not mutually exclusive. In policy and practice, they frequently overlap..$^{29}$ On one hand, international realists and liberal internationalists share a belief that aid should strengthen trading relationships, and that specific aid allocations can legitimately make both donors and recipients better off. On the other hand, liberal internationalists and social-democratic internationalists share a sense that wealthy countries should be concerned with the welfare of the poor. They also share a sense that poverty reduction is in the long-term self-interest of donor countries.

State institutions help to put these different policy approaches into practice. National "bilateral" aid agencies, established by most Western donor countries in the early 1960s, play a key role in development assistance, working alongside international organizations such as the World Bank and the United Nations agencies. Indeed, in this field, as in many others, state institutions are important players in global

27 See e.g. Denis Cogneau \& Jean-David Naudet, "Who Deserves Aid? Equality of Opportunity, International Aid, and Poverty Reduction" (2007) 35:1 World Development 104.

28 See e.g. Jamie Swift \& Brian Tomlinson, eds, Conflicts of Interest: Canada and the Third World (Toronto: Between the Lines, 1991).

29 See Pratt "Humane Internationalism", supra note 19 at 20-21. 
governance. The governments of wealthy countries have vast resources at their disposal as well as a high degree of organizational capacity. ${ }^{30}$

Nevertheless, the pursuit of global justice through state institutions-if this is how bilateral aid is understood-gives rise to a conceptual challenge. While state institutions might be reoriented toward global justice, they are formally accountable only to their home countries' parliaments and citizens. People beyond the state, including aid recipients, typically have no say in the governance of these institutions. These institutions can therefore be said to suffer from a democratic deficit. Or, to use Fraser's terminology, they perpetuate a political injustice: people are excluded from debates in which they ought to be allowed to participate. ${ }^{31}$

One response to allegations of a democratic deficit in development organizations has been to solicit the informal "participation" of aid recipients through surveys, public meetings, and other activities designed to gather input from individuals and communities affected by aid interventions. The idea of participation was initially promoted in the 1980 s by actors who were critical of bureaucratic practices and sought to reform development assistance by dispersing power to its beneficiaries. ${ }^{32}$ However, participatory methods have also been heavily criticized. ${ }^{33}$ One concern is that participatory methods may produce a facade of consensus, masking power relations and political conflicts within the recipient community. Another concern is that participatory methods are unlikely to alter the underlying relationship between donors and

30 In the year 2012, for example, donor country members of the Organisation for Economic Co-operation and Development's (OECD) Development Assistance Committee (DAC) provided over US $\$ 88$ billion in bilateral official development assistance. See OECD, Statistics on Resource Flows to Developing Countries, Table 12, online: <www.oecd.org>.

31 Fraser, supra note 1 at 16-18.

32 See e.g. Robert Chambers, Rural Development: Putting the Last First (Essex: Longman Scientific \& Technical, 1983).

33 See Bill Cooke \& Uma Kothari, eds, Participation: The New Tyranny? (London, UK: Zed Books, 2001). 
recipients. Donor institutions using participatory methods usually retain ultimate decision-making authority.

It should be acknowledged that these allegations of a democratic deficit are mainly aimed at official policy- and decision-making processes. Some scholars have argued that the day-to-day operations of development agencies are much more flexible and responsive to aid recipients than their organization charts would suggest. The anthropologist David Mosse argues that large development organizations have only a limited ability to exercise centralized, hierarchical forms of power. Mosse suggests that the development field contains myriad opportunities for agency and resistance. ${ }^{34} \mathrm{Or}$, as Mosse puts it, "the hegemonic potential of international aid is always limited by this autonomy of practice from policy (and policy from practice)."35

\subsection{Managerialism in DEVELOPMENT ASSISTANCE}

How can organizations responsible for development assistance respond to allegations of a democratic deficit? It may be easier for them to dodge these allegations than to respond to them. If development assistance can be depoliticized, issues of representation and participation may seem less salient. One particularly effective strategy for depoliticizing development assistance has been the portrayal of such activities as essentially technical or managerial.

The mobilization of technical knowledge has long been a central feature of development assistance. During the immediate postwar era, when aid was based on planning and modernization theory, donor institutions relied heavily on macroeconomics. Engineers also held a prominent role: they were needed to build dams, highways, and other

34 David Mosse, Cultivating Development: An Ethnography of Aid Policy and Practice (London, UK: Pluto Press, 2005) at 6-11. See also James Ferguson, The Anti-Politics Machine: "Development," Depoliticization, and Bureaucratic Power in Lesotho (Minneapolis: University of Minnesota Press, 1994) at 280-82.

35 David Mosse, "Global Governance and the Ethnography of International Aid" in David Mosse \& David Lewis, eds, The Aid Effect: Giving and Governing in International Development (London: Pluto Press, 2005) 1 at 23. 
infrastructure. The expansion of development assistance into "social" concerns in the 1960s and 1970s implied the relevance of additional kinds of experts, including medical doctors, public health specialists, biologists, demographers, statisticians, sociologists, and anthropologists. In the neoliberal revolution of the 1980 s, microeconomics became dominant. The "governance" agenda of the 1990s made room for lawyers, and so on. ${ }^{36}$

This reliance on technical knowledge has helped proponents and practitioners of development assistance to portray their work as apolitical. When US President Harry S. Truman announced, in his 1949 inaugural address, that the United States would begin providing aid to "underdeveloped" countries, he emphasized the scientific and technical nature of this enterprise. This emphasis helped Truman overcome resistance from critics who saw such aid as overly political. ${ }^{37}$

Development assistance has not only drawn upon technical expertise; it has also helped to generate its own specialized forms of knowledge. For example, the macroeconomic approaches of the postwar era gave rise, within the academy, to a specialized subfield known as "development economics". The 1960 s and 1970 s turn to "social development" gave rise to new interdisciplinary "development studies" programs. ${ }^{38}$

In addition to scientific and technical knowledge, development assistance organizations have invested a great deal in the elaboration of formal managerial techniques. For example, many development institutions employ "results-based management" processes, specifying quantifiable outcomes and targets for their work, which are used to measure performance. ${ }^{39}$ Scientific and technical knowledge is sometimes

36 See David Kennedy, "The 'Rule of Law,' Political Choices, and Development Common Sense" in David M Trubek \& Alvaro Santos, eds, The New Law and Economic Development: A Critical Appraisal (Cambridge, UK: Cambridge University Press, 2006) 95 [David Kennedy, "Common Sense"].

37 Lumsdaine, supra note 17 at 232-33.

38 See David Kennedy, "Common Sense”, supra note 36.

39 See e.g. Annette Binnendijk, Results Based Management in the Development Co-operation Agencies: A Review of Experience: Background Report (2000) at 10 , 
incorporated into such managerial processes. For example, some economists have devised methods for measuring the number of people lifted out of poverty per aid dollar spent; such measurements could ostensibly guide the allocation of resources. ${ }^{40}$

Such managerial approaches are not confined to development assistance. Indeed, they may be observed in many fields of contemporary global governance. In the last few decades, many governance functions have been assumed by international organizations dealing with subjects such as economics, health, the environment, or security. ${ }^{41}$ In addition, government officials from various countries have established professional networks in which they share information and informally coordinate their activities. ${ }^{42}$ Anne-Marie Slaughter has described such networking in response to issues such as financial instability, corruption, pollution, and terrorism. Slaughter's leading example is the Basel Committee on Banking Supervision, in which the central bankers of 27 countries meet to coordinate their national standards for the capital adequacy of private banks. ${ }^{43}$ The political scientists Kenneth Abbott and Duncan Snidal have also described how non-state actors such as businesses and NGOs have engaged in processes of "regulatory standard-setting" in order to

online: Development Assistance Committee Working Party on Aid Evaluation <www.oecd.org>.

40 World Bank research in the late 1990s suggested that aid would be more effectively used if concentrated in countries with the largest numbers of poor people. See e.g. Paul Collier \& David Dollar, "Aid Allocation and Poverty Reduction” (2002) 46:8 European Economic Rev 1475; Nick Dyer et al, "Strategic Review of Resource Allocation Priorities: Discussion Paper" (2003) [on file with author].

41 See generally Jan Klabbers, An Introduction to International Institutional Law, 2nd ed (Cambridge, UK: Cambridge University Press, 2009).

42 See Robert O Keohane \& Joseph S Nye, "Transgovernmental Relations and International Organizations" (1974) 27:1 World Politics 39.

43 Anne-Marie Slaughter, A New World Order (Princeton, NJ: Princeton University Press, 2004) at $42-43$. 
control the social and environmental effects of transnational business. ${ }^{44}$ A wide variety of actors thus participate in global governance. These actors are brought together by their shared efforts to address particular problems rather than any formal legal or constitutional arrangement.

In recent years, public international lawyers such as Martti Koskenniemi have criticized this trend toward managerialism. As Koskenniemi notes, a managerial approach replaces formal rules with notions such as "interests" and "objectives". But, he argues, such notions are theoretically unsound: they take for granted a set of actors whose "interests" can be objectively determined, when this is never the case. Moreover, the operationalization of such concepts is far from automatic. Professional, expert judgment is required in order to translate these concepts into policies, and in order to apply such policies to particular instances. And each community of experts-whether its specialization is economics, health, environment, or security-brings certain tacit assumptions to its work. Managerial governance is therefore influenced by the biases of whichever type of expertise happens to be dominant. ${ }^{45}$

Koskenniemi's critique of managerialism is linked to a defence of a legal or constitutional approach to world affairs. The shortcomings of managerialism are perhaps most apparent when it is contrasted with the ideal of formal equality that informs international lawyers' professional sensibilities. Nevertheless, Koskenniemi's critique of managerialism is apposite even without this ideal as a reference point. To the extent that domestic laws and institutions purport to address global issues, it is appropriate to subject them to analogous critiques.

With regard to both domestic ("bilateral") and international ("multilateral") development assistance organizations, critics have warned that their management practices and their uses of knowledge give rise to certain biases. For example, donor institutions often generate

44 Kenneth W Abbott \& Duncan Snidal, "Strengthening International Regulation through Transnational New Governance: Overcoming the Orchestration Deficit" (2009) 42 Vand J Transnat'l L 501.

45 Martti Koskenniemi, "Constitutionalism as Mindset: Reflections on Kantian Themes about International Law and Globalization” (2007) 8:1 Theor Inq L 9 at $16-17$. 
macro-level statistical measures, such as per capita income, infant mortality rates, daily caloric intake, life expectancy, and literacy. In recent years, development institutions have aggregated such quantitative, statistical information into a variety of indicators, indices, and rankings. ${ }^{46}$ Perhaps the best known is the United Nations Development Programme's Human Development Index, which aggregates data for income, education, and life expectancy. ${ }^{47}$ Such forms of knowledge create a sense that disparate local circumstances are essentially commensurable. They also imply the possibility of policy models and "best practices": if a program is considered successful, development institutions may attempt to "scale it up" or replicate it elsewhere. ${ }^{48}$ Such practices may serve to hinder development initiatives that have their basis in particularistic local knowledge. ${ }^{49}$

Scholars have offered a number of other critiques of donor agencies' management and knowledge practices. For example, it is argued that the gathering of data serves as a form of surveillance; ${ }^{50}$ that the

46 See Sally Engle Merry, "Measuring the World: Indicators, Human Rights, and Global Governance" (2011) 52:S3 Current Anthropology S83.

47 United Nations Development Programme, Human Development Report 2014, online: <hdr.undp.org/en>.

48 See e.g. UN Millennium Project, online: <www.unmillenniumproject.org>.

49 This is despite the fact that such institutions often proclaim the value of such particularistic local approaches. For example, at the end of the 1990s, the World Bank's chief economist, Joseph Stiglitz, criticized the "one size fits all" nature of structural adjustment reforms and argued for policies that would be more tailored to local society, politics, and institutions. See Joseph E Stiglitz, "Whither Reform?: Ten Years of the Transition" (Paper delivered at the Annual Bank Conference on Development Economics, Washington, DC, 28-30 April 1999), online: <siteresources.worldbank.org/INTABCDEWASHINGTON1999/Resources/stigli tz.pdf>. See also David Kennedy, "Common Sense", supra note 36 at 154-55.

50 See Balakrishnan Rajagopal, International Law from Below: Development, Social Movements and Third World Resistance (Cambridge, UK: Cambridge University Press, 2003) at 104-06. Interestingly, those inclined toward the international-realist approach have sometimes advanced this surveillance function as a justification for aid. For example, in the 1960 s, the Canadian political scientist Keith Spicer, supra note 20 at 51, argued that aid programs should lead to understanding of the 
forward-looking nature of development practices ${ }^{51}$ impedes any serious reflection on the moral legacy of past injustices, such as slavery and colonialism; that the "methodological nationalism" 52 of development assistance obscures the causal role of global economic forces and diverts attention from proposals for global regulation or redistribution; $;^{53}$ and that development assistance enshrines Western-style growth and modernization as a universal model, excluding alternative social visions rooted in identity, culture, or tradition, as well as alternative economic visions based on solidarity or collectivism. ${ }^{54}$

This critical perspective is not intended as a wholesale condemnation of managerialism or of its role in development. It may be entirely appropriate, in some circumstances, to treat poverty as a technical problem to be solved by experts. The point is that such a response to poverty should be recognized as a political choice, rather than as an escape from politics. Managerial processes can never be wholly apolitical; they have important, albeit occasionally subtle, distributive, and discursive effects. Managerialism therefore does not provide a

developing nations' real needs, hopes, fears, prejudices, interests and expectations; to understanding of their mentality, their culture, their society, their government; to understanding, in sum, of their peoples - at every level of life, humble and exalted, to which the day-to-day operations of aid assure a donor access. For aid is the ideal door to dialogue with the peoples of developing nations; it offers a natural, believable excuse to study them at close hand; it provides, through shared experience in their most fundamental long-range preoccupation, concrete and varied opportunities to assess their motivations

51 See David Lewis, "International Development and the 'Perpetual Present': Anthropological Approaches to the Re-historicization of Policy" (2009) 21:1 European J Development Rescarch 32.

52 See generally Ulrich Beck, "Toward a New Critical Theory with a Cosmopolitan Intent” (2003) 10:4 Constellations 453.

53 See Pogge, World Poverty, supra note 13 at 139-44.

54 The idea of "development" has in fact been appropriated and syncretistically reinvented in many different cultural and political contexts. See e.g. Escobar, supra note 16 at 47-52; Rajagopal, supra note 50 at 233-71. But these alternative visions are not necessarily recognized within the development assistance main stream. 
satisfactory way of avoiding allegations of a democratic deficit in the context of state institutions involved in development assistance.

\subsection{DONOR COUNTRY AID LAWS: A BRITISH MODEL}

Many donor countries have enacted laws in relation to their aid programs. At first glance, such laws might seem to provide a formal legal framework for aid allocations - in contrast to a managerial approach. However, upon closer inspection, such laws tend to be consistent with managerialism. They generally empower government officials from the donor country to manage aid in keeping with particular forms of expertise. They may help to insulate aid allocations from external pressures-a separation that helps to reinforce aid managers' claims to stand outside or above politics.

I develop this argument through an account of the United Kingdom's International Development Act $2002^{55}$ and the debates surrounding it. This legislation has significance beyond the United Kingdom. It was part of a package of aid reforms that has been widely hailed as a model for other donor countries to follow. ${ }^{56}$ And, as I shall explain below, it provided the direct inspiration for Canada's ODA Accountability Act.

The International Development Act 2002 has its origins in the mid-1990s, in a controversy involving the use of British aid funds. The UK government had agreed to contribute $£ 234$ million toward the construction of a hydroelectric station in Malaysia, in spite of reports indicating that this dam would be inefficient. Around the same time, Malaysia had purchased over $£ 1$ billion worth of weapons from the United Kingdom. The World Development Movement, an NGO, applied for judicial review of the decision to fund the hydroclectric station, arguing that the true purpose of the aid funding was to provide

55 Supra note 5.

56 See Owen Barder, "Reforming Development Assistance: Lessons from the UK Experience", Working Paper No 70 (2005) at 1, online: Center for Global Development <cgdev.org $>$. 
an inducement for the sale of weapons. ${ }^{57}$ The High Court held that the dam project was "economically unsound" and thus failed to meet the statutory criteria for aid funding; it was, therefore, illegal. ${ }^{58}$ This "Pergau Dam affair", as it came to be known, was a serious embarrassment to the Conservative government of Prime Minister John Major.

When Tony Blair's Labour Party came to power in 1997, it promised sweeping development assistance reforms. Clare Short, the new Secretary of State for International Development, insisted on full ministerial status and a voice in all British policies toward developing countries. $^{59}$ The aid administration was separated from the Foreign Office and re-named the Department for International Development (DFID). A 1997 White Paper declared poverty reduction to be the overall goal of aid policy. ${ }^{60}$ The United Kingdom also fully untied its aid from national procurement requirements, and increased the size of its aid programs. ${ }^{61}$

During Blair's second term, the UK Parliament enacted the International Development Act 2002. The International Development Act 2002 is centred on the concept of poverty reduction. It empowers the Secretary of State to provide development assistance "if he is satisfied that the provision of the assistance is likely to contribute to a reduction in poverty." ${ }^{\prime 2}$ This provision was meant to clarify the purpose of aid to exclude extraneous considerations such as the arms sales that led to the Pergau Dam funding. Clare Short accordingly used the International Development Act 2002 to convince her cabinet colleagues to abandon a

$57 R v$ Secretary of State for Foreign Affairs, ex parte World Development Movement Ltd, [1995] 1 All ER 611, [1995] 1 WLR 386 [cited to All ER].

58 Ibid at 626.

59 See Barder, supra note 56 at 13.

60 See Clare Short, "Eliminating World Poverty: A Challenge for the 21st Century", White Paper on International Development (1997), online: University of Bristol <www.bristol.ac.uk>.

61 See Barder, supra note 56 at 21-22.

62 Supra note 5, s 1(1). 
plan to make aid conditional on recipient countries' acceptance of the return of asylum seekers. ${ }^{63}$

The International Development Act 2002 (and the accompanying package of aid reforms) can be seen as an attempt to promote a socialdemocratic internationalist (or redistributive) concept of aid. However the International Development Act 2002 is largely indifferent to issues of democracy in the delivery of aid. As Patrick McAuslan has observed, the International Development Act 2002 centralizes authority in the office of the Secretary of State for International Development. It leaves most aid decisions up to her discretion, and makes it more difficult for courts to review these decisions. ${ }^{64}$

The International Development Act 2002 focuses on aid, and is silent on other kinds of political-economic relations between North and South. This limitation was vividly illustrated in 2002 when the government of Tanzania sought to buy an air traffic control system from the British company BAE Systems. From Clare Short's perspective, this represented a wasteful use of money that should have been directed toward poverty reduction. Short unsuccessfully tried to convince her cabinet colleagues to block the sale. Defeated at the cabinet table, Short "punished" the Tanzanian government by withholding $£ 10$ million in promised aid. ${ }^{65}$

The Tanzanian air traffic control episode confirms Patrick McAuslan's observations about centralized authority for aid funding under the International Development Act 2002. However, McAuslan's critique of the International Development Act 2002 also revealingly illustrates the tensions among values within the development assistance field. Although McAuslan is critical of the Secretary of State's centralized authority, he stops short of calling for democratization. Instead, he calls for more expert-led management. McAuslan argues that the

63 See Barder, supra note 56 at 21.

64 Patrick McAuslan, "The International Development Act, 2002: Benign Imperialism or Missed Opportunity?" (2003) 66:4 Mod L Rev 563 at 583-85, 596.

65 Ibid at 597. 
International Development Act 2002 should have specified that British aid would be conditional on recipient governments' commitment to poverty reduction, good governance, and human rights. ${ }^{66} \mathrm{He}$ explains:

Rather than just confer power on the Secretary of State to make subjective judgments about whether the provision of any particular form of development assistance will or will not contribute to a reduction in poverty, the Act should have made much more explicit the basic ground rules which will govern the provision and the withdrawal of assistance; the criteria which will be taken into account in determining whether to attach conditions to development assistance; and the duties of the Secretary of State to be accountable to Parliament for the manner in which assistance is provided and its effectiveness measured and evaluated. ${ }^{67}$

McAuslan thus endorses the use of formal legal rules, but he sees these rules largely as bases for disciplinary practices, as ways of strengthening the UK government's bargaining power when it deals with recalcitrant southern country governments. For government and critics alike, then, the ends justify the means; poverty reduction is thought to obviate concerns about power.

The United Kingdom's widely touted aid reforms prompted the Organisation for Economic Co-operation and Development's (OECD) Development Assistance Committec (DAC) to examine the role of donor country legislation in development assistance. In a 2005 report entitled Managing Aid, the DAC noted that roughly half of its members had legislated mandates for their aid programs, while half did not. ${ }^{68}$ Assessing the arguments for and against such legislation, the DAC concluded:

66 Ibid at 587-95.

67 Ibid at 600 [emphasis in original].

68 OECD, DAC Guidelines and Reference Series: Managing Aid: Practices of DAC Member Countries (Paris: OECD, 2005) at 24, online <www.oecd-library.org> [OECD, Managing Aid]. 
A well-developed legislative basis has the advantages of transparency and of clarifying responsibilities among the various government entities that may be involved, as well as establishing development objectives as the main thrust of development co-operation for the whole system. On the other hand, countries with a less formalised legal basis may have more flexibility to act and this could be an advantage when trying to build coalitions between development agencies and other government entities whose policies and actions have an impact on development prospects in developing countries. ${ }^{69}$

The DAC's ambivalence about legislation is symptomatic of a managerial approach. The main significance of aid legislation appears to be its ability to define the scope of the aid program vis-à-vis other government functions. If legislation defines aid in terms of poverty reduction or other "social" priorities, it may act as a firewall to protect aid funds from being diverted for uses that have more to do with security or commercial interests. The question, for the DAC, is whether donor country legislation can help improve development assistance policies. Nowhere is it asked whether law might have a role in clarifying entitlements, rights, and obligations as between donors and recipients, and whether such clarification might have an intrinsic value.

This managerial approach to donor countries' aid laws is all the more remarkable when one considers how it coincided with renewed prescriptions for law reform in recipient countries. During the 1990s, the World Bank and other major donor institutions began to urge recipient countries to reform their legal systems. ${ }^{70}$ This turn to law reform initially reflected economic concerns, as the World Bank began to acknowledge that markets (and market-led economic growth) depend on

69 Ibid.

70 See generally Thomas Carothers, "The Rule of Law Revival" (1998) 77:2 Foreign Affairs 95; Yves Dezalay \& Bryant G Garth, eds, Global Prescriptions: The Production, Exportation, and Importation of a New Legal Orthodoxy (Ann Arbor: University of Michigan Press, 2002); David M Trubek, “The 'Rule of Law' in Development Assistance: Past, Present and Future" in Trubek \& Santos, supra note 36, 74 ['Trubek, "Rule of Law"]. 
"governance" through laws and other institutions. ${ }^{71}$ Donors initially focused on matters such as property law, contract law, and the organization of courts-matters seen as fundamental to the "rule of law". This new emphasis on legal institutions was thus founded on legal formalism, albeit formalism instrumentalized in the name of economic growth. ${ }^{72}$

Around the mid-1990s, this "governance" agenda converged with a renewed emphasis on "social" concerns. In practical terms, economists and social development advocates agreed on such matters as the protection of civil and political rights, the independence of the judiciary, and the elimination of corruption. The convergence of these agendas had the effect of broadening the range of law reform programs; in the late 1990s, the World Bank expanded its governance agenda to include social issues such as gender equality, labour standards, and the environment. But this convergence also helped to moderate the social agenda. ${ }^{73}$

71 See Ibrahim Shihata, The World Bank in A Changing World: Selected Essays (Dordrecht, Netherlands: Martinus Nijhoff, 1991). The origins of such ideas can be traced back to the work of Max Weber. See e.g. Max Rheinstein, ed, Max Weber on Law in Economy and Society (New York: Simon and Schuster, 1954) at 39-40. See also David Trubek, "Max Weber on Law and the Rise of Capitalism" (1972) Wis L Rev 720 . In the early 1990 s, they acquired new vigour thanks to the work of Douglass North and other practitioners of the "new institutional economics", who argued that the wealth or poverty of nations could be significantly attributed to the qualities of their institutions, including the formal and informal laws governing business practices. See e.g. Douglass C North, Institutions, Institutional Change and Economic Performance (Cambridge: Cambridge University Press, 1990).

72 See Trubek, "Rule of Law", supra note 70 at 85-86. This legal formalism set it apart from an earlier generation of law-and-development programs in the $1960 \mathrm{~s}$ and 1970s. See generally David M Trubek \& Marc Galanter, "Scholars in SelfEstrangement: Some Reflections on the Crisis in Law and Development Studies in the United States" (1974) Wis L Rev 1062.

73 See Kerry Rittich, "The Future of Law and Development: Second Generation Reforms and the Incorporation of the Social" in Trubek \& Santos, supra note 36, 203 [Rittich, "Second Generation Reforms"]. 
Nevertheless, the legal certainty that donor agencies prescribed for recipient countries stood in stark contrast to the managerial flexibility that they sought to retain for themselves. There appears to have been an almost complete disconnect between these two reform agendas. The debates surrounding the donor countries' domestic aid reforms were characterized by a lack of reflexivity about the law-and-development agenda being promoted elsewhere.

\section{THE ODA ACCOUNTABILITY ACT: GLOBAL JUSTICE, CANADIAN LAW}

The ODA Accountability Act provides a case study in the use of domestic law to respond to global issues. This Canadian statute, enacted in 2008, stipulates that poverty reduction must be the primary purpose of Canadian aid. As I explain in this part of the article, its creation was initiated by a small group of activists associated with development assistance NGOs. These activists hoped that legislation could help direct Canadian aid toward social priorities such as health and education in the global South. They imagined that Canadian aid could thus respond to global injustices understood in terms of poverty and inequality.

In the following analysis, I note that most of the public debate surrounding the ODA Accountability Act has recapitulated longstanding disagreements about the proper purpose of aid. I show that, in spite of the Act, the Harper government has emphasized the use of aid to pursue Canadian interests. The government has, in effect, refused to see aid as a response to global injustice. Nevertheless, the following analysis also reveals the extent to which global justice advocates chose to promote their goals through a managerial model of development assistance. Moreover, this managerial model was assumed to obviate any concerns about a democratic deficit.

The data in this case study is derived from a variety of documentary sources, including legislation, parliamentary debates, government reports, NGO advocacy materials, and newspaper articles. It is also derived from two dozen semi-structured interviews. Between March and September 2009, I interviewed 3 current or former members of Parliament, 8 NGO staff members or volunteers, and 13 government officials. I initially solicited interviews with people who had been 
publicly involved in the creation of the Act. I asked these participants to recommend others, and I followed some of their leads. Most of the interviews took place in Ottawa-Gatineau, at the offices of the participants. I conducted telephone interviews in two cases where arranging a face-to-face meeting proved impossible.

\subsection{The CONTEXT: CANAdiAn Aid INSTITUTIONS AND POLICIES}

Canada has provided development assistance to countries in the global South for over 60 years. ${ }^{74}$ However, the governance of Canadian aid has historically been rather informal. Until 2008, Canada had no legislation specifying the purpose of its aid programs. Instead, as I explain in this section, the allocation of aid (among countries and among types of programs) has largely been a matter of ministerial and bureaucratic discretion. I also explain how the unstructured nature of this discretion has prompted social-democratic internationalists as well as liberal internationalists to worry about the influence of commercial and security priorities on aid decisions. Activists representing these perspectives have therefore argued that Parliament should strengthen the legal framework for aid.

Debates about Canadian aid policy, and about the potential role of law in structuring aid decisions, have evolved in the context of a particular institutional landscape. Within the federal government, responsibility for development assistance has long been divided among a number of departments and agencies. Debates about aid policy have therefore sometimes taken the form of bureaucratic turf wars. ${ }^{75}$

74 See generally David R Morrison, Aid and Ebb Tide: A History of CIDA and Canadian Development Assistance (Waterloo, Ont: Wilfrid Laurier University Press, 1998).

75 Ibid at 443-45. See also Cranford Pratt, "DFAIT's Takeover Bid of CIDA: The Institutional Future of the Canadian International Development Agency" (1998) 5:2 Canadian Foreign Policy J 1; Stephen Brown, "CIDA under the Gun" in Jean Daudelin \& Daniel Schwanen, eds, Canada Among Nations 2007: What Room for Manoeuvre? (Montreal: McGill-Queen's University Press, 2008) 91 at 93-95 [Brown, "CIDA under the Gun"]. 
From 1968 to 2013, the Canadian International Development Agency (CIDA) distributed the bulk of Canadian aid. In 2009-10, for example, CIDA disbursed over $\$ 3.5$ billion in official development assistance, including $\$ 2.6$ billion in bilateral aid. ${ }^{76} \mathrm{~A} 2009$ report by the Auditor General noted that CIDA had a staff of approximately 1,800 civil servants, including those at its headquarters in Gatineau as well as those posted overseas. ${ }^{77}$ CIDA was represented in cabinet by the Minister for International Cooperation.

A number of other Canadian government actors and institutions have also played key roles in development assistance. Historically, Canadian prime ministers have set the general direction of government policy, including aid policy. ${ }^{78}$ The Department of Finance determines the overall size of the aid budget. It is also responsible for Canada's contributions to the Bretton Woods Institutions. ${ }^{79}$ The Department of National Defence is closely involved in the delivery of Canadian aid in conflict areas. ${ }^{80}$ The foreign ministry, known until recently as the Department of Foreign Affairs and International Trade (DFAIT), has historically overseen certain bilateral programs (in areas such as security and post-conflict reconstruction) as well as Canada's relations with UN

76 CIDA, Report to Parliament on Canada's Official Development Assistance 2009-2010 (Gatineau: CIDA, 2010) at 2-7, online: <www.acdi-cida.gc.ca> [CIDA, 2009-10 Summary Report].

77 Office of the Auditor General of Canada, 2009 Fall Report of the Auditor General of Canada to the House of Commons: Chapter 8: Strengthening Aid Effectiveness-Canadian International Development Agency (Ottawa: Minister of Public Works and Government Services Canada, 2009) at 5, online: <www.oag-bvg.gc.ca> [Auditor General 2009 Report on CIDA].

78 See Bernard Wood, “Managing Canada's Growing Development Cooperation: Out of the Labyrinth" in Jennifer Welsh \& Ngaire Woods, eds, Exporting Good Governance: Temptations and Challenges in Canada's Aid Program (Waterloo, Ont: Wilfrid Laurier University Press, 2007) 225 at 242.

79 See Bretton Woods and Related Agreements Act, RSC 1985, c B-7.

80 See CIDA, Report to Parliament on Canada's Official Development Assistance 2008-2009 (Gatincau: CIDA, 2009) at 22, online: <www.acdi-cida.gc.ca> [CIDA, 2008-09 Summary Report]. 
agencies. A number of other government departments manage small, sector-specific projects relating to security, health, or the environment. ${ }^{81}$ The International Development Research Centre (IDRC), a Crown corporation, funds research in developing countries, as well as research collaboration between Canadian researchers and those in developing countries. ${ }^{82}$

Under these arrangements, CIDA was a separate bureaucratic entity, but it was formally subordinate to DFAIT. CIDA had been established by order-in-council, and it never had its own enabling statute. Its legal mandate was primarily a function of the spending authority it received each year in the annual Appropriation Acts-the budget. And the standard budgetary formulation was extremely open-ended: CIDA was empowered to provide grants, contributions, and payments "for international development assistance, international humanitarian assistance and other specified purposes." ${ }^{83}$ Meanwhile, the Department of Foreign Affairs and International Trade Act granted the Minister of Foreign Affairs "control and supervision" over CIDA. ${ }^{84}$ This legislation also specified that the role of the Minister for International Cooperation-the minister responsible for CIDA - was "to assist the

81 Eight other government departments also reported ODA spending in the government's 2008-09 Summary Report under the ODA Accountability Act. Citizenship and Immigration spent $\$ 92$ million on resettling refugees in Canada, which is considered ODA under the DAC definition. The RCMP, the Departments of National Defence, Health, Environment, Industry, and Parks each had an aid budget of less than $\$ 20$ million each, either for small bilateral projects or for contributions to multilateral organizations. See ibid at 2.

82 A Crown corporation with its own enabling legislation, the IDRC is governed by a board of directors and reports to Parliament through the Minister of Foreign Affairs. See International Development Research Centre Act, RSC 1985, c I-19.

83 See e.g. Bill C-49, An Act for granting to Her Majesty certain sums of money for the federal public administration for the financial year ending March 31, 2010, 2nd Sess, 40th Parl, 2009 (as passed by the House of Commons 19 June 2009) at 21.

84 Department of Foreign Affairs and International Trade Act, RSC 1985, c E-22, s $10(2)(\mathrm{f})$. 
Minister [of foreign affairs] in carrying out the Minister's responsibilities relating to the conduct of Canada's international relations." ${ }^{35}$

In 2013, as part of an omnibus budget bill, the Harper government legislated the merger of CIDA and DFAIT, establishing the Department of Foreign Affairs, Trade and Development (DFATD). The revised legislation empowers the Minister of Foreign Affairs to "foster sustainable international development and poverty reduction in developing countries and provide humanitarian assistance during crises." $\$ 6$ The Minister of International Cooperation has been replaced by a Minister of International Development whose role is "to assist the Minister in carrying out his or her responsibilities relating to international development, poverty reduction and humanitarian assistance." ${ }^{\text {7 }}$

Since the 1950s, it has been widely understood that Canadian aid programs serve a number of policy goals. As the Progressive Conservative Member of Parliament J.M. Macdonnell put it in 1961:

First of all, there is the humanitarian argument. If these people were going to bed hungry just across the road from us we would not go to bed until we had done something about it. Second, there is the political argument which is that it is tremendously in our interests, indeed, it is vital to us, that these underdeveloped countries shall develop economically under free institutions and not under communist institutions.... Then there is the third argument, which some people rather deprecate because it sounds as if we were doing it for our own interests. I have no objection to doing something in our own interests as long as it is in the interests of other people too. ${ }^{88}$

Likewise, five years later, the political scientist Keith Spicer identified Canadian aid as serving a "trinity" of "mixed motives": humanitarian, political, and economic. ${ }^{89}$ In subsequent debates over Canadian aid

85 Ibid, $\mathrm{s} 4$.

86 Department of Foreign Affairs, Trade and Development Act, SC 2013, c 33, s 10(2)(f).

87 Ibid, s 4 .

88 Quoted in Spicer, supra note 20 at 4.

89

Ibid. 
policy, the pursuit of economic development and poverty reduction have often been contrasted with the pursuit of Canadian commercial and security interests. Debates about aid policy have generally concerned the relative priority to be accorded to these goals.

Among Canadian government institutions, CIDA was most closely associated with the pursuit of economic development and poverty reduction. Other departments have had other priorities. The foreign ministry's priority has generally been the pursuit of Canadian national interests, often understood in terms of security or trade. Some departments have sought subsidies for favoured firms or industries. Because CIDA had discretionary spending authority over a large amount of money, ministers and officials from other departments often sought to influence how CIDA's money was spent. ${ }^{90}$

Liberal and social-democratic internationalists, seeking to protect CIDA's priorities, therefore argued for many years that CIDA needed a stronger legal mandate-one that would enable it to resist these intragovernmental pressures. In 1987, a House of Commons committee called for legislation declaring that " $\mathrm{t}$ ] he primary purpose of Canadian official development assistance is to help the poorest countries and people in the world" and that "development priorities" must prevail over "other important foreign policy objectives." 11 This call for legislation was repeated in 1995 by a parliamentary Special Joint Committee. ${ }^{92}$ Finally, in 2007, a Senate Committee chaired by Hugh Segal issued a report containing a scathing critique of Canadian policies toward Africa, largely informed by liberal internationalist principles. This report

90 See Morrison, supra note 74 at 443-45; Wood, supra note 78.

91 House of Commons, Standing Committee on External Affairs and International Trade, For Whose Benefit? Report of the Standing Committee on External Affairs and International Trade on Canada's Official Development Assistance Policies and Programs (Ottawa: Queen's Printer, 1987) at 12.

92 See Morrison, supra note 74 at 388, 395. 
recommended that CIDA either be abolished or given a clear statutory mandate. ${ }^{33}$

\subsection{THE CREATION OF THE ODA ACCOUNTABILITY ACT}

The ODA Accountability Act emerged from this tradition of liberal internationalist and social-democratic internationalist advocacy. It was championed by people who imagined aid as a response to global injustices. Nevertheless, almost all of the participants in the legislative process were Canadian. There was no direct participation from the global South. To the extent that one imagines aid as linked to global justice, the legislative process therefore involved a democratic deficit.

The Canadian Council for International Co-operation (CCIC) led the movement for the ODA Accountability Act. Established in 1968, the CCIC is the principal coalition of Canadian NGOs involved in development assistance. It has approximately 75 member organizations, including Canadian chapters of large international NGOs, local community initiatives, religious groups, and labour unions. ${ }^{94}$

The CCIC's then President-CEO, Gerry Barr, played a key role in the legislative process. The CCIC also enlisted several legally-trained individuals to help draft the legislation. Among these drafters was Vicky Edgecombe, a law student at the University of Ottawa who had written a paper comparing other donor countries' legislation. Vicky Edgecombe's research focused on the International Development Act 2002 as a "starting point for crafting Canadian legislation." 95

Many of the drafters of the ODA Accountability Act would have liked to see Parliament enact a comprehensive enabling statute for CIDA.96

93 Senate, Standing Senate Committee on Foreign Affairs and International Trade, Overcoming 40 Years of Failure: A New Road Map for Sub-Saharan Africa (February 2007) (Chair: The Honourable Hugh Segal), online: <www.parl.gc.ca>.

94 CCIC, "Members", online: <www.ccic.ca>.

95 Vicky Edgecombe, "Establishing a Legal Basis for Canada's Official Development Assistance" (12 January 2005), online: Hon John McKay PC, MP <www.johnmckaymp.on.ca>.

96 Interview of an NGO-affiliated proponent of the Act (24 March 2009). 
The ideal legislation imagined by many of the Act's proponents would have defined CIDA's mandate in terms of poverty reduction, established CIDA's institutional independence, and guaranteed CIDA a stable (and increasing) level of funding. ${ }^{97}$ However, after informal consultations with sympathetic members of Parliament, the CCIC concluded that only the first of these three was likely to win the support of a parliamentary majority. ${ }^{98}$ The CCIC therefore drafted a bill centred on the requirement that Canadian aid be used for the purpose of poverty reduction, obliging the government to report to Parliament on its compliance with this objective. In its original version, the CCIC's bill would also have required the Minister of International Cooperation to appoint an advisory committee, including representatives from NGOs, religious organizations, the private sector, and Parliament. ${ }^{99}$

The opportunity to introduce this legislation arose out of a confluence of domestic and international events. Domestically, a divided Parliament made it possible for individual parliamentarians to succeed with idiosyncratic legislative projects. ${ }^{100}$ Internationally, in 2005, an NGO-led "Global Call to Action Against Poverty" and the G8 summit in Gleneagles, Scotland created a wave of publicity for aid issues. As a consequence, the three Parliamentary opposition leaders (including Stephen Harper) signed an open letter calling on Prime Minister Paul Martin to increase aid levels and to introduce aid legislation. ${ }^{101}$ In June

97 Interview of an NGO-affiliated proponent of the Act (26 March 2009).

98 Ibid.

99 Bill C-293, An Act respecting the provision of development assistance abroad, 1st Sess, 39th Parl, 2006, cl 6 (first reading, 17 May 2006).

100 From 2004 to 2006, Paul Martin's Liberal Party held a plurality but not a majority of seats in Parliament. In 2006, Stephen Harper's Conservative Party was elected, but remained short of a parliamentary majority until 2011.

101 See Jeff Sallot, "Opposition Unites around Foreign Aid", The Globe and Mail (19 February 2005) A4. 
2005, the House of Commons Standing Committee on Foreign Affairs and International Trade reiterated these recommendations. ${ }^{102}$

The CCIC approached several members of Parliament, asking them to sponsor its legislation as a private member's bill. Four private member's bills based on the CCIC's model were introduced in 2005 and 2006. ${ }^{103}$ The version that would ultimately pass was introduced as Bill C-293 on 17 May 2006 by John McKay, a member of the Liberal Party (by this point in opposition). McKay had practised real estate law in Scarborough, Ontario before entering politics in 1997. "One can infer from his professional history that McKay's main exposure to aid issues came from his experience as Parliamentary Secretary to the Minister of Finance from 2003 to 2006. ${ }^{104}$ On my reading, McKay's own views on aid mingled liberal internationalism with Christian (Baptist) humanitarianism.

Bill C-293 was initially supported by the opposition Liberals, New Democrats, and the Bloc Québécois, but opposed by Prime Minister Stephen Harper's Conservative minority government. The proponents' choice of a title for Bill C-293 was strategic. They used the word "accountability" to mirror the Conservative party's political rhetoric and to shame the government into supporting it. ${ }^{105}$

102 House of Commons, Standing Committee on Foreign Affairs and International Trade, Report 12-International Aid, 38th Parl, 1st Sess (9 June 2005).

103 Bill C-446, An Act respecting the provision of development assistance by the Canadian International Development Agency and other federal bodies, 1st Sess, 38th Parl, 2005 (first reading, 16 November 2005); Bill C-204, An Act respecting the provision of development assistance by the Canadian International Development Agency and other federal bodies, 1st Sess, 39th Parl, 2006 (first reading, 6 April 2006); Bill C-243, An Act respecting the provision of development assistance by the Canadian International Development Agency and other federal bodies, 1st Sess, 39th Parl, 2006 (first reading, 1 May 2006); Bill C-293, supra note 99.

104 See John McKay, Biography, "Hon John McKay, MP", online: <www.johnmckaymp.on.ca>.

105 Interview of an NGO-affiliated proponent of the Act (24 March 2009). Compare Federal Accountability Act, SC 2006, c 9. 
During the Bill's passage through the House of Commons, the Standing Committee on Foreign Affairs and International Development amended the bill to remove certain features that would have required fiscal allocations, and thus could not have proceeded without government support. ${ }^{106}$ Most importantly, the provisions for an advisory committee and a petition process were replaced with consultation requirements. With the support of the three opposition parties, Bill C-293 passed its third reading in the House of Commons on 28 March 2007.

The Senate then spent over a year debating Bill C-293. The main protagonists in the Senate were Liberal Senator Roméo Dallaire and Conservative Senator Hugh Segal. Dallaire, famous for his experience as a UN peacekeeper in Rwanda, had later become an advocate for humanitarian intervention in Darfur. Segal, as I have mentioned, had chaired a Senate committee that had produced a highly critical report on Canadian aid to Africa. Although Segal and his Conservative colleagues initially opposed the bill, they relented after the Liberals agreed to certain amendments: the insertion of a reference to the Paris Declaration on Aid Effectiveness, more modest consultation requirements, and a provision ensuring the confidentiality of discussions at the Bretton Woods Institutions. The Senate passed the amended Bill C-293 on 16 April 2008. The amended bill received unanimous approval from the House of Commons shortly thereafter and came into force on 30 June 2008.

The legislative process that led to the ODA Accountability Act was thus almost exclusively a Canadian affair. The core group of activists who put forward the Act was entirely composed of Canadians. Certainly, these activists had numerous personal and professional ties to the global South, and their ideas on global justice were informed by these commitments. However, no one from the global South testified during

106 Constitution Act, 1867 (UK), 30 \& 31 Vict, c 3, s 54, reprinted in RSC 1985, Appendix II, No 5. For a more detailed explanation in reference to an analogous situation, see Richard Janda, "An Act Respecting Corporate Accountability for the Activities of Mining, Oil or Gas in Developing Countries (Bill C-300): Anatomy of a Failed Initiative" (2010) 6:2 JSDLP 97 at 100. 
the parliamentary committee hearings or debated the merits of the Act in other public fora. If people from the global South-the intended beneficiaries of the Act-played any role in the legislative process, it was at best highly indirect.

\subsection{The Legislative TeXT}

The text of the ODA Accountability Act begins by declaring poverty reduction to be the "focus" of Canadian aid:

2. (1) The purpose of this Act is to ensure that all Canadian official development assistance abroad is provided with a central focus on poverty reduction and in a manner that is consistent with Canadian values, Canadian foreign policy, the principles of the Paris Declaration on Aid Effectiveness of March 2, 2005, sustainable development and democracy promotion and that promotes international human rights standards.

The Act's main substantive provisions, subsections 4(1) and 4(1.1), are also concerned with the purpose of aid. These provisions stipulate that ministers responsible for providing aid must be satisfied that this aid meets certain conditions:

4. (1) Official development assistance may be provided only if the competent minister is of the opinion that it

(a) contributes to poverty reduction;

(b) takes into account the perspectives of the poor; and

(c) is consistent with international human rights standards.

(1.1) Notwithstanding subsection (1), official development assistance may be provided for the purposes of alleviating the effects of a natural or artificial disaster or other emergency occurring outside Canada.

The consequences of a failure to meet these criteria are found in subsection 4(3), which states:

(3) In calculating Canada's official development assistance contribution in Government of Canada publications, the competent minister or the Governor in Council shall consider only official development assistance as defined by this Act that meets the criteria in subsections (1) and (1.1). 
In other words, the Canadian government can still fund projects that do not contribute to poverty reduction, etcetera, but it can no longer refer to them as "official development assistance" in its publications.

It is worth noting that the Act contains a circularity. The limits set by section 4 only apply to "official development assistance", which is a term defined to mean international assistance that meets the criteria set out in section 4. Section 3 of the Act states that:

"official development assistance" means international assistance

(a) that is administered with the principal objective of promoting the economic development and welfare of developing countries, that is concessional in character, that conveys a grant element of at least $25 \%$, and that meets the requirements set out in section 4; or

(b) that is provided for the purpose of alleviating the effects of a natural or artificial disaster or other emergency occurring outside Canada.

The remaining provisions of the Act have to do with consultation and reporting. Subsection 4(2) specifies that the ministerial opinion cannot arise in a vacuum, but must be the result of consultations with certain groups:

(2) The competent minister shall consult with governments, international agencies and Canadian civil society organizations at least once every two years, and shall take their views and recommendations into consideration when forming an opinion described in subsection (1).

Section 5 of the Act requires ministers to submit two reports to Parliament each year. Subsection 5(1) sets out the requirements for the first of these reports, unofficially known as a summary report, due six months after the end of each fiscal year (i.e., 30 September). In this document, each department must state the total amount of its aid disbursements and provide "a summary of any activity or initiative taken under this Act". Subsection 5(2) requires the government to provide a full statistical account of Canadian aid one year after the end of each fiscal year (31 March).

Finally, the ODA Accountability Act also deals with the Canadian government's participation in international donor institutions. 
Subsection 5(3) requires the Minister of Finance to disclose "the position taken by Canada on any resolution that is adopted by the Board of Governors of the Bretton Woods Institutions", and to justify Canada's activities vis-à-vis the Bretton Woods Institutions (BWIs) in terms of the substantive values of the ODA Accountability Act. However, these obligations are qualified by subsection 5(4), which guarantees the confidentiality of discussions held at the BWIs.

\subsection{The InTENTIONS Of THE PROPONENTS}

The proponents of the $O D A$ Accountability Act intended it to mandate a social approach to aid policy, with some concessions to an economic approach. Above all, they intended it to exclude the use of aid for the pursuit of Canadian commercial and security interests. However, the proponents of the Act also looked to managerialism as the best way to pursue these policy goals. In effect, the design of the ODA Accountability Act reveals its proponents' faith in managerial, expert-led governance.

From the proponents' perspective, the lynchpin of the ODA Accountability Act is paragraph 4(1)(a), which requires Canadian aid to be focused on poverty reduction. Poverty reduction is also given top billing in the Act's statement of purpose. Some proponents of the Act understood poverty reduction in "social" terms, linking it to the provision of social services such as "clean wells" and "schools for kids". ${ }^{107}$ Others linked poverty reduction to economic development. Several expressed hope that the emphasis on poverty reduction would help to exclude certain forms of aid, most notably security-related forms of aid such as those linked to the NATO campaign in Afghanistan. ${ }^{108}$ Some proponents also argued that "tied" aid, or the use of aid to promote Canadian commercial objectives, would be prohibited under

\footnotetext{
107 Interview of an NGO-affiliated proponent of the Act (26 March 2009).

108 Interview of an NGO-affiliated proponent of the Act (24 March 2009); interview of an NGO-affiliated proponent of the Act (24 March 2009); interview of an NGO-affiliated proponent of the Act (17 August 2009).
} 
the Act. ${ }^{109}$ As John McKay put it, the Act was meant to "protect development money from being redirected towards Canadian security projects and business interests and from ever changing 'flavour of the week' policies." 110

However, the proponents of the Act also chose to entrust the application of this requirement to the minister responsible for providing aid. The test provided in subsection $4(1)$ is entirely subjective. Provided that "the competent minister" has formed an opinion that the aid in question would contribute to poverty reduction, it would be almost impossible to challenge the minister's decision. Moreover, subsection 4(1) stops short of demanding that the minister allocate aid on the basis of need. The minister is not required to select the aid policy or program that would reduce poverty the most. The Act only deals with one aid allocation decision at a time. An aid policy or program could reduce poverty only minimally or incidentally and still be considered acceptable under the Act. In addition, section 1.1, which sets aside the poverty reduction requirement in cases of disaster relief, could also be construed to allow ministers to provide aid for a wide variety of other purposes.

Why, then, did its proponents imagine that such a mechanism would help to further their approach to aid policy? The answer is that they had faith in an expert-led model of development assistance, which they associated with CIDA. They saw CIDA, an institution staffed by development experts, as the government actor most likely to share their vision of development assistance and of global justice. They identified other government departments, such as Foreign Affairs and Finance, as the main threats. Reliance on ministerial judgment was meant to insulate CIDA from intragovernmental political pressures. ${ }^{111}$ The Act's proponents deliberately avoided stipulating objective criteria, because

109 Interview of an NGO-affiliated proponent of the Act (31 March 2009).

110 John McKay, News Release, "Liberal MP McKay Calls on Conservative Government to Stand Up for Poverty Reduction" (20 September 2006), online: <www.johnmckaymp.on.ca>.

111 Interview of a Member of Parliament (18 March 2009); Interview of an NGO-affiliated proponent of the Act (20 March 2009). 
they did not want to hamper the flexibility of aid practices, especially those of CIDA.

It must be acknowledged that the proponents of the Act were fully aware of the subjective nature of the criteria in subsection 4(1) and of the ambiguity of terms like "poverty reduction". They therefore accompanied this substantive requirement with processes that they hoped would help ensure the government's fidelity to a "social" approach to development. Foremost among these is the "perspectives of the poor" requirement in paragraph $4(1)(b)$. This provision lends weight to a "social" interpretation of poverty reduction, while hinting at the democratization of aid processes. Thus, according to the CCIC, paragraph $4(1)(b)$ means that "Canadian ODA must be delivered in a manner that builds capacities of affected populations to participate in all dimensions of development affecting their lives". ${ }^{12}$

Likewise, the Act's proponents described its consultation and reporting requirements as ways of increasing transparency and public participation in aid delivery. By stipulating that CIDA (and other departments) must engage in consultations, the proponents of the Act sought to enlist a wider constituency-including non-governmental actors-in the project of interpreting the legislation. They imagined an alternative community of interpretation for the Act that would help fend off pressures coming from elsewhere in government. ${ }^{113}$ As I have noted, the Act's proponents understood the consultation requirements as a substitute for their preferred option, an advisory committee representing various stakeholder groups. In the original version of the Bill, this committee would have been able to receive petitions from developing-country residents, should they wish to complain that Canadian aid was inconsistent with the purposes of the Act. The committee would have decided whether to forward these petitions

112 Brian Tomlinson, "International Human Rights Standards and Canadian ODA: Implications and Issues of the Canadian ODA Accountability Act: A CCIC Briefing Note" (November 2008) at 19, online: CCIC <www.ccic.ca> [Tomlinson, "Implications and Issues"].

113 Interview of an NGO-affiliated proponent of the Act (20 March 2009). 
to the minister; if it had done so, the minister would have been obliged to respond. ${ }^{114}$

The Act's consultation and reporting requirements, as well as the "perspectives of the poor" requirement, were meant to involve a wider constituency in aid policy making and enhance the transparency of aid decisions. However, these provisions cannot be said to bring about a true democratization of aid. Even in the hoped-for petition process, the role of Canadian constituencies would have been much more powerful than that of poor people in the global South. As enacted, the law mainly provides for accountability toward Canadians. The government must report to the Canadian Parliament. It must consult with "governments, international agencies and Canadian civil society organizations" 115 _but not necessarily with civil society organizations in recipient countries, nor with aid recipients themselves. And the government has the last word. During the parliamentary hearings, when Senator Raynell Andreychuk suggested that the consultation requirements in subsection 4(3) should include the poor, John McKay replied, "Senator Andreychuk you argued that it should be a right of the poor to have their perspectives taken into account. That is a bridge too far. This is still the discretion of the Canadian people as represented by their minister and government." 116

The limited democratization imagined by the Act's proponents, their modest use of accountability mechanisms, is essentially consistent with standard models of "participatory development" (see Part 2.1, above). Moreover, for the Act's proponents, these procedural mechanisms were meant to buttress a particular substantive vision of aid. The proponents' vision of global justice was thus one in which expert managers would pursue a modest form of redistribution, but not necessarily one in which those who were to benefit from this redistribution would have a loud

114 See Bill C-293, supra note 99, cl 6-8. It is interesting to compare this imagined petition process with the process that existed under the League of Nations mandate system. See Rajagopal, supra note 50 at 67-71.

115 ODA Accountability Act, supra note 2, s 4(2).

116 Senate, Standing Senate Committee on Foreign Affairs and International Trade, Proceedings (June 2007) at 24 (Chair: John McKay). 
voice. Although the proponents of the Act hoped to respond to justice claims coming from outside Canada, they were content to allow Canadian institutions to decide how to respond to these claims, on the basis of their superior expertise.

On the whole, the proponents of the Act placed their trust in bureaucratic discretion, hoping that this discretion could be infused with values similar to their own. In this regard, it is revealing that, despite their objections to the government's subsequent policy changes, the proponents have generally refrained from accusing the government of breaking the law. Instead, they have argued that the government is violating the "spirit" of the law or failing to implement it properly. ${ }^{117}$ One proponent of the Act expressed the view that Canadian development NGOs would prefer to avoid litigation, because it might lead to an overly precise interpretation of the Act. ${ }^{118}$

\subsection{THE GOVERNMENT’S RESPONSE}

The government of Prime Minister Stephen Harper initially opposed Bill C-293. However, it later relented, and tepidly endorsed the bill. The amendments secured by Senator Hugh Segal, discussed earlier, facilitated this about-face. But so did the government's realization that the terms of the ODA Accountability Act could be interpreted to be consistent with its policy preferences: economic development and the pursuit of Canadian commercial and security interests. To the dismay of the Act's proponents, the Harper government has adopted an international-realist approach to aid, and it has interpreted the Act to be consistent with such an approach.

Before proceeding with this analysis, it is important to acknowledge that "the government" is not monolithic. A wide range of views on aid policy can be found among Canadian government officials. In particular,

117 See Gerry Barr, "ODA Accountability Act: Remarkable Legislation, Disappointing Implementation" in CCIC, $A$ Time to Act: Implementing the ODA Accountability Act: A Canadian CSO Agenda for Aid Reform (Ottawa: CCIC, 2010) 5 at 12, online: <www.ccic.ca> [CCIC, Time to Act].

118 Interview of an NGO-affiliated proponent of the Act (24 March 2009). 
the views of development bureaucrats are not necessarily the same as those of the political leadership. However, for the sake of convenience, I refer to the position of "the government" when summarizing the general policy direction adopted by the Harper cabinet. I specify particular governmental actors where it is necessary to explain divergences.

While Bill C-293 was being debated in Parliament, the new government's approach to aid policy remained unclear. The government's foreign policy was focused on the war in Afghanistan; with regard to aid, it emphasized the integration of aid into the war effort as part of a " 3 -D" or "whole of government" approach. ${ }^{119}$ However, after the Act came into force, the government introduced further policy changes reflecting a concern for the pursuit of Canadian commercial and security interests, the projection of conservative moral values, and to some extent, economic development. And it introduced these policy changes without any explicit reference to the $O D A$ Accountability Act. $^{120}$

For example, in February 2009, CIDA announced that its previous list of 25 "countries of concentration" would be narrowed to 20 "countries of focus". ${ }^{21}$ The number of African countries on the list was halved, whereas Latin American countries were added. ${ }^{122}$ This shift was widely regarded as motivated by Canadian commercial and security interests. An aide to Minister for International Cooperation Beverley J. Oda called the decision "a function of need, of the capacity to deliver aid

119 See Brown, "CIDA under the Gun", supra note 75; Erin Simpson, "From Inter-Dependence to Conflation: Security and Development in the Post-9/11 Era" (2007) 28:2 Can J Development Studies 263.

120 See Stephen Brown, "Aid Effectiveness and the Framing of New Canadian Aid Initiatives" in Stephen Brown, ed, Struggling for Effectiveness: CIDA and Canadian Foreign Aid (Montreal: McGill-Queen's University Press, 2012) 79 at 97-98 [Brown, "Aid Effectiveness"] [Brown, Struggling for Effectiveness].

121 See ibid.

122 See CIDA, News Release, "Canada Moves on Another Element of its Aid Effectiveness Agenda” (23 February 2009), online: <www.acdi-cida.gc.ca>. 
effectively, and supporting Canada's foreign policy". ${ }^{123}$ One country added to the list was Colombia; at the time of the announcement, the government was seeking parliamentary approval for a new bilateral trade agreement with Colombia.

In May 2009, Minister Oda announced that CIDA's work would henceforth focus on the themes of "food security," "sustainable economic growth," and "children and youth." 24 Later, "security and stability" and "democracy" were added. ${ }^{125}$ In January 2010, Prime Minister Stephen Harper announced that he would use Canada's hosting of the 2010 G8 and G20 summits to promote maternal and child health in developing countries-but categorically declared that Canadian funds would not be used to provide access to abortion. ${ }^{126}$

In November 2012, new CIDA minister Julian Fantino confirmed a shift in policy toward "partnership" with the private sector. He cited examples of education projects operating alongside Canadian mining companies. He also spoke of aid as a way of opening markets for Canadian firms, declaring, "CIDA takes an upstream approach to economic growth. We help to make countries and people, trade and investment ready." 127 Fantino also underlined the ongoing relevance of security goals, stating that aid "safeguards Canadian security by

123 Clark Campbell, "Canada Seeks Strategic Ties by Focusing Aid on Americas", The Globe and Mail (23 February 2009) A13.

124 CIDA, "A New Effective Approach to Canadian Aid: Speaking Notes for the Honourable Beverley J. Oda Minister of International Cooperation at the Munk Centre for International Studies", online: <www.acdi-cida.gc.ca> [Oda Toronto Speech].

125 See CIDA, 2009-10 Summary Report, supra note 76 at 5.

126 See e.g. Joanna Smith, "No Support for Funding Abortion: PM Harper Says Canadians Don't Want to Be Split Over Use of Foreign Aid", Toronto Star (28 April 2010) A 10.

127 CIDA, "Minister Fantino's Keynote Address to the Economic Club of Canada Titled 'Reducing Poverty-Building Tomorrow's Markets", online: $<$ www.acdi-cida.gc.cas. 
addressing sources of instability and preventing threats before they reach our borders". ${ }^{128}$

The absorption of CIDA by the foreign ministry in 2013 thus consummated a gradual policy shift. In general, the Harper government has seen aid as a way of pursuing Canadian commercial and security goals. The government accepts that aid can help support economic development, although it tends to prioritize countries where Canada has strategic interests. The government sometimes uses the language of charity or generosity to describe Canadian aid commitments, but never the language of moral obligation.

The government's approach to the interpretation of the $O D A$ Accountability Act reflects this international-realist policy orientation. The government has responded to the "poverty reduction" requirement in paragraph $4(1)(a)$ in two ways. On one hand, it has argued for an economic rather than a social understanding of this requirement, maintaining that economic growth is the means to reduce poverty. Second, it has often simply minimized the significance of this requirement, or emphasized its vagueness and open-endedness. In interviews, some officials emphasized that poverty reduction should include both "direct" and "indirect" approaches. ${ }^{129}$ One referred to poverty reduction as a "comprehensive concept" that can include economic growth, education, health, or justice sector reform. ${ }^{130}$ Some specified that poverty reduction should also be understood to include security-related aid and peacekeeping. ${ }^{131}$ According to one official, poverty reduction is merely a "semantic game": one can argue that anything does or does not reduce poverty. ${ }^{132}$ Generally, CIDA officials

\footnotetext{
128 Ibid.

129 Interview of a government official (24 June 2009).

130 Interview of a government official (28 September 2009).

131 Interview of a government official (20 May 2009).

132 Interview of a government official (19 May 2009).
} 
took the position that the poverty reduction provisions merely confirmed CIDA's existing priorities. ${ }^{133}$

The government's first four summary reports under the Act reflect both of these approaches to poverty reduction. These documents describe the kinds of aid provided in the previous fiscal year, implying that ministers are of the opinion that these contribute to poverty reduction. But few reasons are given for these opinions; contributions to poverty reduction are generally asserted rather than explained or justified. For example, the word "poverty" appears only twice in CIDA's section of the first summary report, once as part of the blanket assertion that "CIDA supports programs and projects with poverty reduction as their primary objective." 134 The second, third, and fourth summary reports contain more references to poverty, but for CIDA, poverty was increasingly subsumed under the heading of "sustainable economic growth". Interestingly, the fifth summary report, covering CIDA's final year as a separate entity, places a greater emphasis on poverty reduction as an overarching theme. ${ }^{135}$

Other departments have been even more explicit about their economic approach to poverty reduction. For example, the Department of Finance argues that debt relief for poor countries reduces poverty by freeing up resources "for use in more productive investments (e.g., health, education, infrastructure, etc.) that support long-term economic growth and development." 136 DFAIT argued that its program of scholarships for foreign students "contributes to poverty reduction by developing a skilled workforce, leading to economic growth and development" and that its Investment Cooperation Program "supports

133 CIDA, “ODA Accountability Act Implementation Steering Committee (29 October 2008): Record of Discussion" [on file with author].

134 CIDA, 2008-09 Summary Report, supra note 80 at 3.

135 Department of Foreign Affairs, Trade and Development (DFATD), Report to Parliament on the Government of Canada's Official Development Assistance 2012-2013 (Ottawa: DFTAD, 2013), online: <www.acdi-cida.gc.ca> [DFATD, 2012-13 Summary Report].

136 CIDA, 2009-10 Summary Report, supra note 76 at 11. 
responsible, developmentally beneficial, private sector investments in developing countries leading to sustained economic growth and poverty reduction." ${ }^{137}$

Government officials have also adopted a minimal, procedural reading of the "perspectives of the poor" requirement. The government has generally taken a position that its practices were always compliant with the Act. Indeed, internal discussions at CIDA focused on documenting the fact that the perspectives of the poor have been ascertained. ${ }^{138}$ In a document released shortly after the Act came into force, CIDA declared:

CIDA has long considered the perspectives of the poor as part of its normal design and management processes. Officials typically have used a range of options to gather the perspectives of the poor for international assistance activities. The options may include: reviews of relevant research material, reports from other donor organizations, site visits, consultations with the intended recipients, relevant civil society organizations, individuals with particular expertise, or with officials of democratically elected partner governments. In order to demonstrate compliance with the Act, the perspectives of the poor that are taken into account via these mechanisms should be documented as appropriate. ${ }^{139}$

The government's first summary report under the Act contained no references whatsoever to the perspectives of the poor. The second summary report contained a single reference, in which CIDA asserted that it takes into account the perspectives of the poor through "[a] variety of formal and informal processes ... such as consultations with local partners and beneficiaries, participatory approaches, project review processes and policy dialogue." 140 In the third report, CIDA simply stated that each of its substantive programming themes "is linked to

137 Ibid at 16.

138 See CIDA, "ODA Accountability Act Implementation Steering Committee (29 October 2008): Record of Discussion" [on file with author].

139 CIDA, "CIDA's Business Process RoadMap version 3.3 (July 2008)" [on file with author]. This paragraph was dropped from subsequent versions of this document.

140 CIDA, 2009-10 Summary Report, supra note 76 at 3. 
poverty reduction and takes into account the perspectives of the poor." ${ }^{141}$ The fourth report merely acknowledged that taking into account the perspectives of the poor is a requirement of the act. ${ }^{142}$ The fifth report repeated this acknowledgment, while adding (in a passage discussing a contribution by the Department of Finance to the Catalyst Fund managed by the World Bank's International Finance Corporation) that the International Finance Corporation's investment objectives "broadly respect the spirit of the Act regarding poverty reduction, perspectives of the poor, and human rights." 143

The government has also taken a narrower, more formal view of the Act's reporting and consultation requirements. CIDA was already in the habit of publishing a number of annual reports, including a detailed annual statistical report. CIDA officials therefore seized on the Act's reporting requirements as a public relations opportunity. ${ }^{144}$ The government's first five summary reports have been remarkably user-friendly documents, providing quantitative information about Canadian aid while also supplying a sense of background and context for aid projects - something that was often missing from CIDA's previous annual statistical reports.

Government departments have also adopted a minimal reading of the Act's consultation requirements. Anecdotal evidence suggests that CIDA's practices of consulting with NGOs have in fact declined in recent years. Indeed, shortly after the Act came into force, CIDA

141 CIDA, Report to Parliament on the Government of Canada's Official Development Assistance 2010-2011 (Gatineau: CIDA, 2011), online: <www.acdi-cida.gc.ca> [CIDA, 2010-11 Summary Report] at 3.

142 CIDA, Report to Parliament on the Government of Canada's Official Development Assistance 2011-2012 (Gatineau: CIDA, 2012), online: <www.acdi-cida.gc.ca> [CIDA, 2011-12 Summary Report] at 1.

143 DFATD, 2012-13 Summary Report, supra note 135.

144 Interview of a government official (19 May 2009). 
adopted a more directive stance toward the NGOs it helps to fund. ${ }^{145}$ In November 2009, CIDA terminated its funding of Kairos, a church-based NGO that had supported civil society groups in many southern countries. Officially, CIDA merely stated that Kairos's work no longer fit with its programming priorities. But unofficially, the government made it clear that Kairos had been singled out for its (allegedly) critical stance toward Israeli policies. ${ }^{146}$ Over the next few months, government officials directly or indirectly warned other NGOs that their advocacy activities might cost them their CIDA funding. ${ }^{147}$ In 2010, after 40 years of continuous funding, CIDA cut off its support for the CCIC. ${ }^{148}$

The proponents of the Act had hoped that "poverty reduction", left in the hands of expert managers, would dictate a social approach to development. But the government's response showed that this concept could be rendered compatible with a national interests-based aid policy. The proponents of the Act had also hoped that "the perspectives of the poor" and procedural requirements could be imbued with substance. But the government's response showed that such provisions could also be treated as pure formalities. On the whole, the government's interpretation and implementation of the Act showed that the

145 See Stephen Brown, "CIDA's New Partnership with Canadian NGOs: Modernizing for Greater Effectiveness?" in Brown, Struggling for Effectiveness, supra note $120,287$.

146 Speaking at a conference in Jerusalem in December 2009, Immigration Minister Jason Kenney said that the government had cut Kairos's funding because of its alleged involvement in a campaign to boycott Israel. See Jeff Davis, "Kenney's Combative Christmas", Embassy (6 January 2010) 2. It was later revealed that, despite her earlier parliamentary denials, Oda had flouted the advice of her own officials in deciding to "de-fund" Kairos. See Bill Curry \& Gloria Galloway, "Oda Admits to Changing Memo, Harper Tories Accused of Secrecy", The Globe and Mail (15 February 2011) A1.

147 See Clark Campbell, "Aid Groups Told to Keep Quiet on Policy Issues”, The Globe and Mail (12 February 2010) A4.

148 See Lee Berthiaume, "Cutting Out the Development NGO 'Heart", Embassy (9 June 2010) 1. 
managerial approaches of the Act's proponents could not withstand an open political repudiation. The political leadership looked askance at the professional sensibilities of the experts and managers on which the proponents of the Act had pinned their hopes, and the Act contained nothing that would constrain the government's policy direction. In this regard, it is telling that, although the Harper Conservatives have held a parliamentary majority since 2011 , their government has never publicly raised the possibility of amending or repealing the Act.

\section{INTERNATIONAL NORMS AND STANDARDS IN THE ODA ACCOUNTABILITY ACT}

The ODA Accountability Act contains references to a number of international norms and standards. These include the reference, in the preamble, to the Paris Declaration on Aid Effectiveness; the reference to "international human rights standards" in paragraph $4(1)(\mathrm{c})$; and the Act's definition of "official development assistance", which is adapted from the definition used by the OECD's Development Assistance Committee. Although the Act was made in Canada, it contains a number of imported parts.

It might be argued that such international references mitigate any democratic deficit vis-à-vis people beyond Canada's borders. It might also be argued that the legal qualities of some of these norms and standards, especially human rights, serve to alleviate the Act's tendencies toward managerialism. However, neither of these arguments withstands closer scrutiny. First, the institutions that have generated such norms and standards often suffer from democratic deficits-they are not representative of the people aid is meant to help. Second, despite some gestures toward democratization, the norms and standards contained in the Act, including human rights, may be interpreted as consistent with a managerial approach to aid.

Indeed, the proponents of the ODA Accountability Act recognized, to some extent, the democratic shortcomings of aid institutions and of the norms and standards they generate. As I explain in this part of the article, the original version of the Act contained a number of provisions that implicitly criticized such institutions, by requiring the government to report on its activities at the Bretton Woods Institutions, and by 
attempting to redefine "official development assistance". However, during the parliamentary process, these critical provisions were effectively neutralized. The Act now reflects a largely deferential stance toward the global governance of development assistance.

\subsection{DEMOCRATIC DEFICITS AND MANAGERIALISM IN INTERNATIONAL AID ORGANIZATIONS}

The ODA Accountability Act contains a number of references to norms and standards developed outside Canada. However, these norms and standards do not necessarily enhance the Act's claim to be a mechanism for the pursuit of global justice. This is because the institutions that have generated these standards are not democratically governed. It is also because these standards tend to be interpreted in keeping with a managerial approach to development assistance.

It is widely acknowledged that bilateral aid may serve the interests of the donor country in addition to, or at the expense of, the interests of the recipient country. In contrast, multilateral aid, that is, aid managed by international organizations, is sometimes portrayed as more neutral-less politicized. ${ }^{149}$ In practice, however, bilateral and multilateral aid are not clearly separated; national aid agencies often work in close collaboration with international organizations. As the Auditor General of Canada put it in 2009 with reference to CIDA:

CIDA does not act alone. It is part of a larger development community, globally and at a country-specific level-a community that also influences CIDA's programming. This community includes aid agencies from other donor countries, development banks, United Nations and other multilateral institutions, civil society and nongovernment organizations, and the governments of recipient countries. ${ }^{150}$

Moreover, despite aspirations toward neutrality, the governance structures of the international organizations that deal with development

149 See e.g. Commission on International Development, Partners in Development: Report of the Commission on International Development (London: Pall Mall, 1969).

150 Auditor General 2009 Report on CIDA, supra note 77 at 8. 
assistance are not necessarily representative of the people they are meant to help. For example, on the governing bodies of the World Bank-the largest multilateral development agency in terms of amounts disbursed ${ }^{151}$ - voting shares are allocated according to a complex formula loosely based on countries' levels of investment in the Bank. On the Executive Board of the International Bank for Reconstruction and Development (the Bank's largest lending arm), the United States controls over $16 \%$ of the vote, whereas the countries of sub-Saharan Africa collectively have just over $5 \%$ of the vote. ${ }^{152}$ Moreover, the US government is able to influence the World Bank's policies and lending decisions through informal contacts or threats of political retaliation. ${ }^{153}$ And since the World Bank's founding in 1944, it presidents have always been US citizens, nominated by the US government.

Another important donor-controlled organization is the OECD's Development Assistance Committee. Headquartered in Paris, the OECD is an association of 34 (mainly Western) countries sharing a "commitment to market economies backed by democratic institutions". ${ }^{154}$ The OECD conducts technical analyses, sets standards, and issues recommendations on a wide variety of policy issues. With its decentralized administrative structure, it has been described as "an amalgam of a rich man's club, a management consulting firm for

151 The World Bank committed US\$52.6 billion in loans, grants, and other outlays during the 2012 fiscal year. The largest amount (US\$20.6 billion) came from the International Bank for Reconstruction and Development, but over a quarter (US $\$ 14.7$ billion) came from the International Development Association. See World Bank, Press Release, "World Bank Group Support to Promote Growth and Overcome Poverty in Developing Countries Hits Nearly $\$ 53$ Billion in 2012" (29 June 2012), online: <www.worldbank.org>.

152 See World Bank, "International Bank for Reconstruction and Development: Voting Power of Executive Directors", online: <www.worldbank.org>.

153 See Ngaire Woods, "The International Monetary Fund and the World Bank" in Mary Hawkesworth \& Maurice Kogan, eds, Encyclopedia of Government and Politics, 2nd ed (London, UK: Routledge, 2003) 953.

154 OECD, "About the OECD", online: <www.oecd.org/about>. 
governments, and a legislative body."155 Within the OECD, the Development Assistance Committee (DAC) is the main point of intersection among Western countries' bilateral aid agencies. ${ }^{156}$ The DAC provides a forum where donor countries can discuss aid policies and try to reach consensus, resulting in non-binding policy recommendations. DAC members submit their aid programs to detailed "peer reviews", conducted by development experts from other donor countries. Recipient countries are not formally represented.

Norms and standards generated by international organizations therefore do not necessarily reflect the outcome of any representative process. The institutions that generate them may not grant much political voice, if any, to people in the global South. References to these norms and standards in domestic legislation therefore do little to offset any democratic deficit vis-à-vis those people.

A further concern about these international norms and standards is that they may help to reinforce a managerial approach to aid. The best example of managerialism in international norms and standards is perhaps the Paris Declaration on Aid Effectiveness, which is cited in the preamble to the ODA Accountability Act. This international declaration was the outcome of a series of meetings organized by the DAC during the late 1990s and early 2000s. Over 130 countries (both donors and recipients) and all of the principal multilateral donor agencies now adhere to the Paris Declaration. ${ }^{157}$

The Paris Declaration urges the delivery of aid through programs rather than projects. It exhorts donor countries to increase their reliance on recipient countries' systems for procurement and financial management, to reduce the number of parallel implementation

155 James Salzman, "Decentralized Administrative Law in the Organisation for Economic Cooperation and Development" (2005) 68:3-4 Law \& Contemp Probs 189 at 191.

156 OECD, "The Development Assistance Committee's Mandate", online: <www.oecd.org>.

157 See OECD, "Countries, Territories and Organisations Adhering to the Paris Declaration and AAA", online: <www.oecd.org>. 
structures, and to undertake more joint field missions. It recommends mechanisms for transparency and reporting. It also endorses the untying of aid. The implementation of these and other reforms is to be measured according to a schedule of 12 progress indicators.

These detailed reform proposals are accompanied by discursive elements that convey the impression of equality between donors and recipients. Although not a legally binding instrument, the Paris Declaration mimics the form of a collective contract between aid donors and recipients (the latter referred to as "partner countries"). It is structured around five principles: "ownership" (recipient countries are to "exercise effective leadership over their development policies"); "alignment" (donors are to "base their overall support on partner countries' national development strategies, institutions and procedures"); "harmonization" (donors are to coordinate their activities to ensure their complementarity and avoid duplication); "managing for results" ("implementing aid in a way that focuses on the desired results and uses information to improve decision-making"); and finally, "mutual accountability" ("[d]onors and partners are accountable for development results"). ${ }^{158}$

However, the principles of the Paris Declaration are potentially contradictory. The most evident tension is that between "harmonization", on one hand, and "alignment" and "ownership", on the other. For example, in Zambia and in Mozambique, donor countries have joined together to coordinate their dealings with recipient governments (in keeping with the principle of harmonization). ${ }^{159} \mathrm{But}$ the collective power of donors may make it harder for recipient governments to make indigenous policy choices. Harmonization may therefore be achieved at the expense of ownership and alignment. Moreover, the concept of "ownership" is itself ambiguous. On one hand, "ownership" sounds like a stronger version of "alignment". On the other

\footnotetext{
158 OECD, "Paris Declaration on Aid Effectiveness and the Accra Agenda for Action", online: <www.oecd.org> at 3-8.

159 OECD, Managing Aid, supra note 69 at 85.
} 
hand, "[o]wnership is often used by donors to mean commitment to policies, regardless of how those policies were chosen." 160

The Paris Declaration mediates such tensions through concepts such as "partnership" and "mutual accountability". "Partnership" evokes a sense of equality. "Mutual accountability" implies that all forms of accountability are mutually supportive; it glosses over the possibility of conflict. Thus, the 2008 Accra Agenda for Action-the follow-up to the Paris Declaration-declared that "citizens and taxpayers of all countries expect to see the tangible results of development efforts.... We will be accountable to each other and to our respective parliaments and governing bodies for these outcomes." ${ }^{161}$

But the most powerful way of mediating the tensions among the Paris Declaration's principles has been to subordinate all of them to the overriding goal of "effectiveness". The notion of "effectiveness" sounds unobjectionable in principle. However, there are also reasons to be skeptical about a discourse of "effectiveness". First, as the political scientist Stephen Brown has observed, it is rarely possible to credit aid programs for significant social and economic changes; such changes are slow and have multiple causes. ${ }^{162} \mathrm{~A}$ second concern arises from the fact that "effectiveness" implies instrumental rationality and the achievement of mutually agreed goals. To emphasize effectiveness is to assume that political questions have been settled and that only managerial or technical questions remain. The Paris Declaration is therefore consistent with a managerial model of development assistance.

This notion of "effectiveness" has thoroughly permeated aid discourse in Canada, as in many other countries. In 2002, for example,

160 Paolo de Renzio, Lindsay Whitfield \& Isaline Bergamaschi, "Reforming Foreign Aid Practices: What Country Ownership Is and What Donors Can Do to Support It", at 2, online: <www.iese.ac.mz/lib/saber/fd_4002.pdf)>.

161 OECD, Accra Agenda for Action (2008) at para 10, online: <www.oecd.org>.

162 Brown, "Aid Effectiveness", supra note 120 at 86-88. 
CIDA issued a "Policy Statement on Strengthening Aid Effectiveness". ${ }^{63}$ In her major policy speech in May 2009, Minister Beverley J. Oda declared that she had made effectiveness CIDA's "top priority." 164 The Auditor General's 2009 review of CIDA was entitled "Strengthening Aid Effectiveness" and used CIDA's 2002 Policy Statement on Strengthening Aid Effectiveness as its standard of measurement. ${ }^{165}$

When the DAC first began promoting its effectiveness agenda, it linked this agenda to the achievement of a set of quantifiable substantive goals: halving the number of people living in poverty, universalizing primary education, eliminating gender disparities in primary and secondary education, reducing child mortality, improving maternal health, and achieving environmental sustainability. ${ }^{166}$ In 2000 , these goals (along with two others: halting the spread of HIV/AIDS, malaria,

163 CIDA, "Canada Making a Difference in the World: A Policy Statement on Strengthening Aid Effectiveness" (Hull, Que: CIDA, 2002), online: <www.acdi-cida.gc.ca>.

164 Oda explained effectiveness as "[e]fficiency to squeeze the most out of every dollar; Focus and priorities to maximize impact and results; and Greater transparency and accountability so that Canadians see how their tax dollars make a difference in the developing world": Oda Toronto Speech, supra note 124. Ineffectiveness is the most common source of popular doubt about aid in Canada. See OECD, Canada: Development Assistance Committee (DAC) Peer Review (Paris, France: OECD, 2007) at 27, online: <www.oecd.org>. Canada stands out among donor countries for the proportion of people (67\%) who both support aid programs and consider them ineffective; the proportion in most DAC countries is less than 20\%. See Roger C Riddell, Does Foreign Aid Really Work? (Oxford: Oxford University Press, 2007) at $116 \mathrm{ff}$.

Auditor General 2009 Report on CIDA, supra note 77 at 32-33.

See OECD, DAC, Shaping the 21st Century: The Contribution of Development Co-operation (Paris, France: OECD, 1996) at 8-11, online: <www.oecd.org>. Interestingly, in this report, the DAC also subtly challenged certain background assumptions about development assistance. It raised questions about the "coherence" of donor countries' policies toward the global South, hinting that donor countries bore some responsibility for global poverty and inequality. It implied that northern countries should consider reducing their trade barriers and curtailing their arms exports (see ibid at 18). However, these themes were dropped from subsequent DAC publications. 
and tuberculosis, and creating a global partnership for development) were incorporated into the United Nations Millennium Declaration. The governments of 189 countries thus declared their intention to achieve these goals by 2015. ${ }^{167}$ Since 2000, governments and development institutions have frequently referred to these Millennium Development Goals (MDGs) as setting a direction for development policy. ${ }^{168}$ The MDGs are also accompanied by several dozen "targets" and "indicators", which the UN has used as the basis for annual progress reports. ${ }^{169}$

Nevertheless, the vision of effectiveness enshrined in the Paris Declaration is somewhat self-referential, emphasizing managerial process rather than substance. ${ }^{170}$ Most of the Paris Declaration's indicators measure the implementation of bureaucratic changes rather than social or economic outcomes. For example, indicators include increasing the use of program-based approaches, increasing the use of recipient countries' systems for procurement and financial management, reducing the number of parallel implementation structures, and undertaking more joint field missions and analysis. These procedural aspects of the aid effectiveness agenda confirm that development is the domain of a particular community of experts who know how to manage these processes.

167 United Nations Millennium Declaration, GA Res 55/2, UNGAOR, 55th Sess, Supp No 49, UN Doc A/55/49 (2000).

168 For example, CIDA declared in 2008 that "over the past ten years, a global consensus has emerged on the goals and principles of development cooperation"; it explained this by citing the Millennium Development Goals, the Monterrey Consensus on Financing for Development, and the Paris Declaration on Aid Effectiveness: CIDA, Estimates 2008-09: Part III: Report on Plans and Priorities (Gatineau: CIDA, 2008) at 8 , online: <www.tbs-sct.gc.ca>.

169 See Kerry Rittich, "Governing by Measuring: The Millennium Development Goals in Global Governance" in Helene Ruiz Fabri, Rudiger Volfrum \& Jana Gogolin, Select Proceedings of the European Society of International Law, Volume 2, 2008 (Oxford: Hart, 2010) 463 at 463.

170 See also Stephen Brown, "Introduction: Canadian Aid Enters the Twenty-First Century" in Brown, Struggling for Effectiveness, supra note 120, 3 at 6-8. 
Reliance on international norms standards in domestic legislation is thus insufficient to offset concerns about a democratic deficit vis-à-vis people in other countries. Moreover, a closer look at such international norms and standards reveals that they, too, may be infused with a managerial ethos. Such norms and standards may therefore help domestic institutions avoid questions of representativeness and accountability rather than respond to them.

\section{2 "INTERNATIONAL HUMAN RIGHTS STANDARDS"}

International norms also appear in the $O D A$ Accountability Act in the form of a reference to "international human rights standards" in paragraph $4(1)(c)$. This provision could potentially be read as a formal guarantee of rights in the context of development assistance. However, the proponents of the Act have argued for an interpretation that subsumes human rights within a managerial approach to aid. And to the extent that human rights are understood as formal legal guarantees, the Canadian government has rejected their applicability.

The idea of human rights was originally elaborated in the context of domestic constitutional arrangements. Nevertheless, after the Second World War, human rights appeared on the agenda of international organizations (notably the United Nations). Moreover, many southern leaders embraced the language of human rights as part of their struggles for self-determination and sovereignty. The constitutions of many African states made explicit reference to the Universal Declaration of Human Rights. ${ }^{171}$

Human rights first became an important factor in global politics in the late 1970s due to grassroots mobilization and Cold War strategy, as well as more general changes in legal consciousness. ${ }^{172}$ Many citizens of northern countries were attracted to human rights as an appeal to morality against superpower politics. ${ }^{173}$ Human rights appeared to offer

171 See Moyn, supra note 12 at 109-14.

172 See Duncan Kennedy, "Three Globalizations of Law and Legal Thought: $1850-2000 "$ in Trubek \& Santos, supra note 36,19 at 63-71.

173 See Moyn, supra note 12 at 3-8. 
the promise of transcending a nationalist approach to justice, formalizing moral duties beyond borders. At the same time, northern governments (beginning with the administration of US President Jimmy Carter) also embraced human rights in order to infuse their foreign policy with a moralizing quality. By the 1980 s, northern human rights activists had become professionalized and media-savvy; governments, international organizations, and transnational corporations were all using the language of human rights. ${ }^{174}$

When, in the late 1970 s, donor country governments took up the cause of human rights in the context of development assistance, they focused exclusively on civil and political rights. Moreover, donor country governments invoked human rights mainly as conditions that recipient governments would have to respect in order to receive aid. ${ }^{175}$ Human rights thus gave northern countries (especially the United States) a way to pressure southern countries to adopt a liberal model of the state. However, southern countries also used the language of rights to defend a more centralized, egalitarian vision of the state: they used their majority in the UN General Assembly to pass the 1986 Declaration on the Right to Development. ${ }^{176}$

During the 1980s, donor institutions also began to integrate human rights concerns into traditional development programs, for example by emphasizing gender equality in education and nutrition. Donor institutions also began to undertake dedicated rights-promotion and "democratization" activities: for example, supporting rights-based civil society groups and rights-oriented legal and political institutions. Official Western enthusiasm for human rights and democracy promotion reached a crescendo by 1990 , coinciding with the toppling

174 See Nicolas Guilhot, The Democracy Makers: Human Rights and International Order (New York: Columbia University Press, 2005) at 178-82.

175 See Ian Smillie, "Boy Scouts and Fearful Angels: The Evolution of Canada's International Good Governance Agenda" in Welsh \& Woods, supra note 78, 41 at 46-47; Morrison, supra note 74 at 159-62.

176 Declaration on the Right to Development, GA Res 41/128, annex, UNGAOR, 41 st Sess, Supp No. 53, UN Doc A/41 (1986) 186. 
of oppressive regimes in Eastern Europe, Latin America, South Africa, and elsewhere. ${ }^{177}$

Following the end of the Cold War, Western governments and development institutions displayed a greater openness to claims of economic, social, and cultural rights. The 1993 UN Conference on Human Rights in Vienna emphasized the indivisible and interdependent nature of human rights. ${ }^{178}$ In the aid context, "social development" issues, which in the 1960s and 1970s had often been described in terms of human needs, were increasingly reframed in terms of human rights. ${ }^{179}$ There were also increasing attempts to demonstrate the compatibility of development with civil and political rights. ${ }^{180}$ Scholars such as Amartya Sen made sophisticated attempts to redefine development in terms of human rights. ${ }^{181}$ Since the late 1990 s, the mutual reinforcement of rights and development has become a truism in the development field, reproduced through claims that poverty is itself a human rights

177 See Morrison, supra note 74 at 323. In Canada, this era saw the establishment of the International Centre for Human Rights and Democratic Development ("Rights \& Democracy"), which would be dismantled in 2012 by the Harper Conservatives.

178 Vienna Declaration and Programme of Action, UN Doc A/CONF157/23 (1993).

179 However, many development institutions continue to resist framing "social" issues in rights terms. Although the Bretton Woods Institutions have given renewed attention to social concerns since the mid-1990s, their approach to human rights remains largely individualistic and indifferent to distributive concerns. For example, these institutions support formal gender equality but stop short of demanding programs to achieve substantive equality; they also support protection for individual workers' legal rights but fail to endorse collective labour rights. In essence, social concerns are acknowledged only to the extent that they are seen as congruent with dominant approaches to economic growth. See Rittich, "Second Generation Reforms", supra note 73 at 225-27. See also Upendra Baxi, The Future of Human Rights (New Delhi: Oxford University Press, 2002) at 15-17.

180 See e.g. Boutros Boutros-Ghali, quoted in Rajagopal, supra note 50 at 145, 149.

181 Amartya Sen, Development as Freedom (New York: Anchor Books, 1999). 
violation $^{182}$ and that human rights are both intrinsically valuable and instrumental to development. ${ }^{183}$

Nevertheless, within major development institutions, human rights have often been integrated into a managerial approach. In 1997, UN Secretary General Kofi Annan directed all UN agencies to "mainstream" human rights into their work. In 2003, UN agencies reached a "Common Understanding" on human rights-based approaches to development. ${ }^{184}$ Many national and international development agencies have also embraced this concept. ${ }^{185}$ Human rights-based approaches are said to include attention to inclusivity and non-discrimination in the provision of aid, participation in decision-making, and accountability through national and international mechanisms.

Taken at face value, human rights-based approaches would seem to incorporate egalitarianism as well as challenge power structures. However, critics have also warned that human rights mainstreaming may have the effect of subordinating human rights to other projects, reducing human rights into a managerial checklist. ${ }^{186}$ Many development

182 See e.g. Mary Robinson, "What Rights Can Add to Good Development Practice" in Philip Alston \& Mary Robinson, eds, Human Rights and Development: Towards Mutual Reinforcement (Oxford: Oxford University Press, 2005) 25 at 27.

183 See OECD, "DAC Action-Oriented Policy Paper on Human Rights and Development" [on file with author].

184 United Nations Population Fund, "The Human Rights-Based Approach", online: $<$ www.unfpa.org/human-rights-based-approach>.

185 See e.g. OECD, "DAC Action-Oriented Policy Paper on Human Rights and Development" [on file with author]; United Kingdom, Department for International Development, "How-to Note: A Practical Guide to Assessing and Monitoring Human Rights in Country Programmes", online: The National Archives $<$ webarchive.nationalarchives.gov.uk>.

186 See generally Martti Koskenniemi, "Human Rights Mainstreaming as a Project of Power" (2006), online: New York University <www.iilj.org>; Andrea Cornwall \& Celestine Nyamu-Musembi, "Putting the 'Rights-Based Approach' to Development into Perspective" (2004) 25:8 Third World Quarterly 1415. 
institutions treat human rights as a consideration, without acknowledging corresponding human rights obligations. ${ }^{187}$

The approach to human rights favoured by proponents of the $O D A$ Accountability Act is consistent with these trends in the development assistance field. Proponents of the Act argue that "poverty reduction" and "perspectives of the poor" must be read in combination with "international human rights standards". 188 For some of the Act's proponents, paragraph $4(1)(c)$ refers not only to civil and political rights but also to economic, social, and cultural rights such as the rights to food, water, education, and health. ${ }^{189}$ This interpretation links human rights to social development, as aid policies must be designed to fulfill these rights and must not contribute to their violation. The CCIC's Brian Tomlinson argues that "[p]olicies and practices in Canadian ODA must, as required by international human rights standards, fully respect, but also, protect and promote international human rights." ${ }^{190}$

187 See Adam McBeth, "A Right by Any Other Name: The Evasive Engagement of International Financial Institutions with Human Rights" (2009) 40:4 Geo Wash Int'l L Rev 1101.

See e.g. Canada, Parliament, Senate, Standing Senate Committee on Foreign Affairs and International Trade, Proceedings, 39th Parl, 1st Sess, No 17 (6 June 2007) at 40 (Molly Kane) (invoking language pulled directly from the ODA Accountability Act).

The first legal challenge to be filed under the Act was nevertheless framed in terms of civil and political rights. The government of Ethiopia had charged a Canadian citizen, Bashir Makhtal, with terrorism-related offences for his alleged involvement in a regional separatist movement in Ethiopia. Mr. Makhtal initially faced the death penalty; he was convicted in July 2009 and sentenced instead to life imprisonment. In April 2009, Mr. Makhtal's Canadian lawyer, Lorne Waldman, filed an application for judicial review alleging that Ethiopia was violating Makhtal's human rights and consequently called for the withholding of Canadian aid to Ethiopia. The application was subsequently discontinued. See Michelle Shephard, "Lawsuit Challenges Aid to Ethiopia: Imprisoned Canadian's Lawyer Accuses Ottawa of Giving Relief to State that Doesn't Respect Rights", Toronto Star (3 April 2009) A18; David McDougall, "How a Business Trip Ruined a Man's Life", The Globe and Mail (1 August 2009) A14.

190 Brian Tomlinson, "An Overview: An Agenda for Change-Implementing the ODA Accountability Act" in CCIC, Time to Act, supra note 117, 11 at 29. 
Nevertheless, the proponents' approach to "international human rights standards" is also a managerial one. The CCIC argues that paragraph $4(1)(c)$ requires the government of Canada to consider the human rights implications of its programming decisions and to exercise due diligence to ensure that its aid is not undermining human rights. ${ }^{191}$ The CCIC's interpretation is essentially consistent with the human rights-based approaches favoured by large international aid organizations. According to the CCIC's Gerry Barr, "a human rights approach to aid spending, and only a human rights approach, will meet the requirements of the Act." ${ }^{192}$

The government of Canada has used a mixture of strategies to respond to the challenge of paragraph $4(1)(\mathrm{c})$. On one hand, it has accepted a modest form of human rights mainstreaming, but one that is limited to civil and political rights. In its deliberations about the implementation of the Act, CIDA took the position that it satisfied the human rights requirement through its attention to gender equality and participation and through its governance programming. In its portion of the government's second summary report under the Act, CIDA summed up its human rights position as follows: "CIDA supports several human rights activities in many countries, and ensures that its programs do not contribute, directly or indirectly, to violations of human rights." ${ }^{193}$

On the other hand, the government has at times invoked a more formal, legal understanding of human rights-but has used this understanding to limit the applicability of human rights in development assistance. Human rights are imagined as the exclusive responsibility of host country governments. In interviews, some government officials expressed the opinion that Canadian aid would only run afoul of paragraph $4(1)(c)$ if Canada were funding a specific activity that violated human rights, or if Canada were giving direct budget support to an oppressive regime. In internal legal opinions, the government has also

\footnotetext{
191 See Tomlinson, "Implications and Issues", supra note 112 at para 18.

192 Barr, supra note 117 at 5.

193 CIDA, 2009-10 Summary Report, supra note 76 at 3.
} 
taken the position that its own human rights obligations are territorially bounded. Some CIDA officials argue that, as a government institution, CIDA is already bound by Canada's international human rights obligations, and that paragraph $4(1)(\mathrm{c})$ is therefore redundant. ${ }^{194}$ The CIDA Steering Committee on the Implementation of the Act concluded that "current compliance with [paragraph] 4(1)(c) of the Act presents communications, not compliance challenges." ${ }^{195}$

The ODA Accountability Act's appeal to "international human rights standards", like its appeal to the Paris Declaration, should therefore not necessarily be understood as enhancing its legitimacy vis-à-vis people in the global South. The reference to human rights seems unlikely to provide a counterpoint to the managerialism characteristic of much of the Act. Human rights can easily be subsumed within a managerial approach to development assistance, or they can be formally interpreted as having a limited scope of application. In neither case does paragraph $4(1)(c)$ seem likely to enhance the Act's contribution to global justice.

\subsection{Failed Challenges to the Global Governance of DEVELOPMENT ASSISTANCE}

The proponents of the ODA Accountability Act, to their credit, recognized some of the shortcomings of international development organizations and the norms and standards they generate. They therefore sought to legislate certain provisions that implicitly challenged these modes of governance. Nevertheless, in order to get their legislation through Parliament, they agreed to amendments that effectively neutralized these challenges.

The clearest example of this phenomenon can be found in subsection 5(3), which requires the Minister of Finance to report to Parliament on Canada's activities at the Bretton Woods Institutions. In parliamentary hearings, the proponents of the Act explicitly linked this provision to a

194 CIDA, “ODA Accountability Act Implementation Steering Committee (14 November 2008): Record of Discussion" [on file with author].

195 Ibid. 
critique of these institutions and of their governance practices. NDP Member of Parliament Alexa McDonough argued that the Bretton Woods Institutions were insufficiently transparent, and that the purpose of this provision was "to see the lid pried off some of that confidentiality." ${ }^{196}$ Nevertheless, subsection 5(3) encountered strenuous objections from the governing Conservative party. In order to achieve a parliamentary consensus, the proponents of the Act agreed to the insertion of subsection 5(4), which guarantees respect for the confidentiality of discussions at the Bretton Woods Institutions.

However, perhaps the most interesting example of a failed challenge to global governance can be found in the Act's definition of "official development assistance". The definition found in the Act is a modified version of the definition agreed upon by members of the OECD's Development Assistance Committee:

Official development assistance is defined as those flows to countries and territories on the DAC List of ODA Recipients ... and to multilateral development institutions which are:

i. provided by official agencies, including state and local governments, or by their executing agencies; and

ii. each transaction of which:

a) is administered with the promotion of the economic development and welfare of developing countries as its main objective; and

b) is concessional in character and conveys a grant element of at least 25 per cent (calculated at a discount rate of 10 per cent). ${ }^{197}$

Under the DAC definition, ODA can come in almost any form; the most significant exclusion is military aid. ${ }^{198}$ Donor countries use this definition to compare the sizes of their aid contributions.

196 Canada, Parliament, House of Commons, Standing Committee on Foreign Affairs and International Development, Evidence, 39th Parl, 1st Sess, No 32 (28 November 2006) at 16 (Alexa McDonough).

197 OECD, "Is it ODA? Factsheet-November 2008", online: <www.oecd.org>.

198 See OECD, "DAC Statistical Reporting Directive, Annex 2" (12 November 2010) at para 42, online: <www.oecd.org>. 
The DAC definition of ODA contains some items that rile social-democratic internationalists (as well as some liberal internationalists). For example, when donor countries cancel developing countries' debts, the amount of the write-off is counted as ODA-meaning that ODA figures can be inflated through the accumulation of interest. The DAC definition also allows donor countries to include the cost of supporting and integrating refugees during their first year in the donor country-a praiseworthy expenditure, perhaps, but one that arguably contributes little to social or economic development in these refugees' home countries. Finally, in 2005, DAC donors agreed to recognize certain security-related activities as ODA, such as civilian oversight of military institutions and programs to reduce the proliferation of light weapons. ${ }^{199}$

Supporters of Bill C-293 argued that such activities should not count as ODA. They sought to narrow the concept of ODA by legislating a new definition. ${ }^{200}$ The $O D A$ Accountability Act's definition is based on the DAC definition, but it adds the criteria listed in section 4 (i.e., poverty reduction, perspectives of the poor, and international human rights, except in cases of disaster relief). The proponents hoped that this definition would ensure a social (or at least an economic) approach to aid. However, the Act's drafters inadvertently made their definition broader than the DAC's in one respect: they neglected to specify which countries can be ODA recipients.

Government officials quickly recognized that the Act could be interpreted to broaden the definition of ODA to include aid to Russia and some other Eastern European countries that are not on the DAC list of ODA recipients. ${ }^{201}$ CIDA officials also mused that military and security-related aid could arguably be justified in terms of poverty

199 See OECD, "Conflict Prevention and Peace Building: What Counts as ODA?", online: <www.oecd.org>.

200 In French, however, the two terms are different: The ODA Accountability Act's term is "aide au développement officielle", whereas the DAC's is "aide publique au développement".

201 Interview of a government official (21 May 2009). 
reduction. ${ }^{202}$ Officials from some departments, notably the Department of Finance, asked why Canada should not adopt such a broadened definition. ${ }^{203}$

Nevertheless, CIDA officials chose to prioritize consistency with the DAC definition. They were concerned that the Act would place Canada out of step with other DAC donor countries. One official testifying in Parliament called it "awkward" that some aid expenditures would be reportable as ODA under the DAC definition but not under the Act, and vice-versa. ${ }^{204}$ Ultimately, a CIDA committee decided to interpret the Act's definition to be as close as possible to the DAC definition. (However, the two definitions cannot be identical because the $O D A$ Accountability Act only applies to the federal government, whereas the DAC definition also includes contributions from provincial governments.) With the support of DFAIT, CIDA then convinced other departments to do the same. ${ }^{205}$ This approach meant that some of the more controversial inclusions under the DAC definition, such as refugee resettlement costs, were ultimately included under the $O D A$ Accountability Act definition as well. ${ }^{206}$

The proponents' attempt to legislate a made-in-Canada definition of "official development assistance" can be understood as a modest challenge to the DAC and its standard-setting authority. However, its critical potential was compromised by poor legislative drafting, and its proponents ultimately left this challenge in the hands of CIDA and other government institutions unwilling to carry it forward. The

202 Interview of a government official (20 May 2009).

203 CIDA, "Meeting Summary: Third ODA Accountability Act Interdepartmental Meeting: 7 April 2009" [on file with author].

204 House of Commons, supra note 196 at 2 (Michael Small).

205 CIDA, "Meeting Summary: Third ODA Accountability Act Interdepartmental Meeting: 7 April 2009" [on file with author]; CIDA, "ODA Accountability Act Implementation Steering Committee (20 April 2009): Meeting Summary” [on file with author].

206 See e.g. CIDA, 2008-09 Summary Report, supra note 80 at 19. 
challenge was ultimately neutralized: the global standard trumped the domestic statute.

\section{CONCLUSION}

In this article, I have tried to show that the proponents of the $O D A$ Accountability Act relied on managerialism to escape the problem of a democratic deficit vis-à-vis people outside Canada. The Act was designed to protect the integrity of managerial approaches to poverty reduction. It also drew on international norms and standards, but did so in a way that did little to enhance its democratic credentials.

While this article focuses on the ODA Accountability Act, a similar critical perspective could perhaps be brought to bear on other attempts to mobilize domestic law in response to global injustices, now or in the future. There can be no doubt that contemporary global affairs involve a panoply of injustices. In an era when Canadian citizens (like citizens of many other countries) are increasingly conscious of global affairs, it is understandable that they should want to respond to these injustices. It is also understandable that they should seek to mobilize the mechanisms they know best-domestic laws and institutions-in pursuit of this objective.

However, global injustices can be characterized in many different ways. Depending on one's perspective, these injustices may appear as immediate crises or as long-term trends; their causes may appear as global or local. While managerial practices and the application of expert knowledge may help to solve particular problems, the solutions they offer may also limit how we understand these problems, and thus limit the range of possible responses. In the context of development assistance, a managerial approach often implies drawing boundaries around the possible forms of social and economic change-for instance, attributing the causes of national wealth or poverty to indigenous factors, and assuming that poverty must be alleviated through growth rather than redistribution.

Legal and institutional responses to global injustices should therefore, in principle, be based on processes that are representative and democratic. This democratic imperative poses a serious obstacle to the 
mobilization of domestic laws and institutions in pursuit of global justice. (Likewise, this democratic imperative provides reason for skepticism about many global institutional responses to global injustice.) A perfect way of overcoming this challenge is unlikely to be forthcoming. Even at the national scale, democracy is always a work in progress. Once one seeks to define the relevant political community beyond the state, the challenge is even more daunting. ${ }^{207}$

My argument is not, however, that one should avoid taking up this challenge. My argument should be understood, rather, as a criticism of certain ways of avoiding this challenge. Managerialism, much like legal formalism, can provide the appearance of an escape from politics. Nevertheless, responses to injustice, at a global scale or a local one, will always involve political choices.

207 See Fraser, supra note 1 at $48-75$. 